University of Louisville

ThinkIR: The University of Louisville's Institutional Repository

Electronic Theses and Dissertations

1940

\title{
The relative influence of raw material components upon the thermal expansion of vitreous enamel.
}

\author{
Robert C. Boyd \\ University of Louisville
}

Follow this and additional works at: https://ir.library.louisville.edu/etd

Part of the Chemical Engineering Commons, and the Engineering Physics Commons

\section{Recommended Citation}

Boyd, Robert C., "The relative influence of raw material components upon the thermal expansion of vitreous enamel." (1940). Electronic Theses and Dissertations. Paper 1677.

https://doi.org/10.18297/etd/1677

This Master's Thesis is brought to you for free and open access by ThinkIR: The University of Louisville's Institutional Repository. It has been accepted for inclusion in Electronic Theses and Dissertations by an authorized administrator of ThinkIR: The University of Louisville's Institutional Repository. This title appears here courtesy of the author, who has retained all other copyrights. For more information, please contact thinkir@louisville.edu. 
HAue of strdens: Soput $\leq$ Boyd TITL OF THESIS: THE RELATIVE IMFLUENCE OP RAW WA TSRIAI COMPOHEHTS UPOH THE THRRLAL EXPANSION OF VI TRROUS ENAMEI

APPROVBD BY READING COMIT TESB COMPOSED OF THE

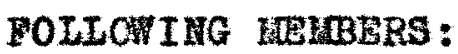

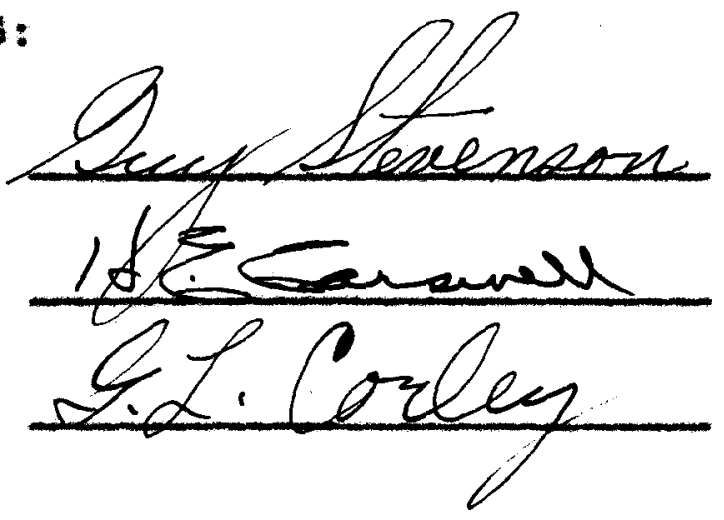

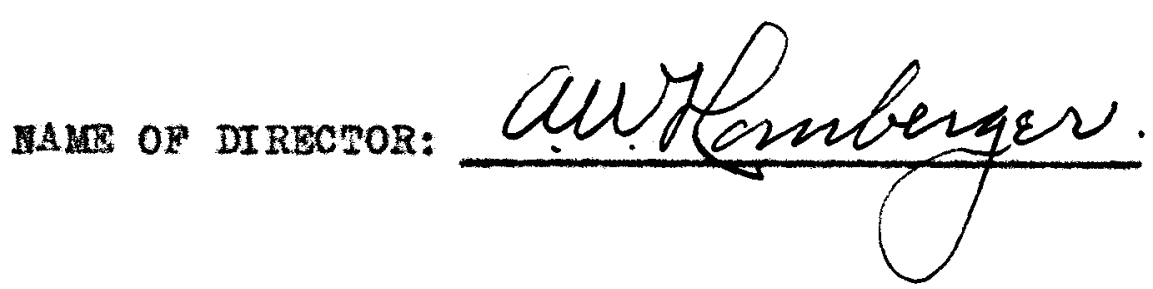
DATS: $\frac{\operatorname{man} 24,1940}{y}$ 


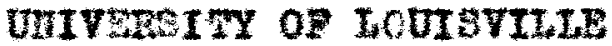

Frs nut

OF RA

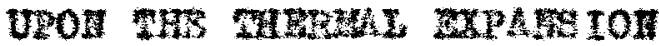

of VITREOUS EXALE

\author{
A Dacertation \\ Subrat ted to the Yrearty \\ of the Creduate sohool of the Dniveroity of Louisvizie \\ In pertial gulfillwent of the \\ Reguirements tor the Degree \\ of uneter of Sclones
}

Departent of Chodistry

by

Bobert C. Boyd

1940 


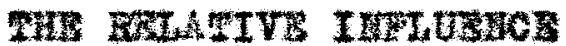

of Ru

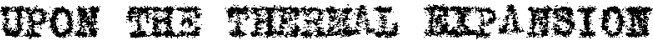

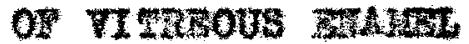




\section{and of contrins}



TABTE

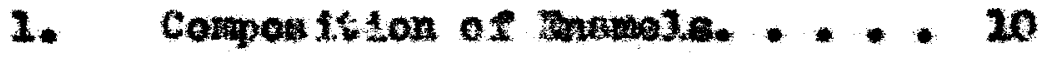

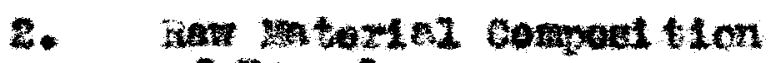
of munelis. . . ........ 14

3. Deta............... 30 Deta feontinnod........ 3 Date (continned), ....... 38 jata (continted)....... 38

4. Voluris coefflesonts of

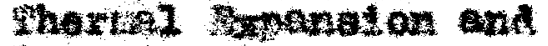
Oxila ructors .......... 38

5. Compsion of oxide Fectors. . 39 


\section{MrouR}

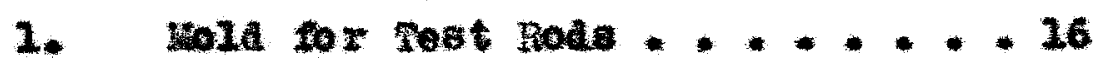

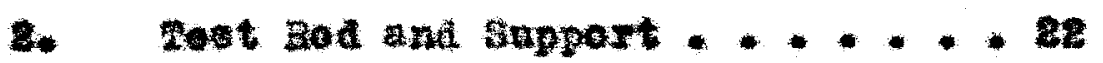

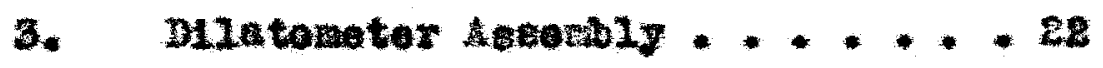

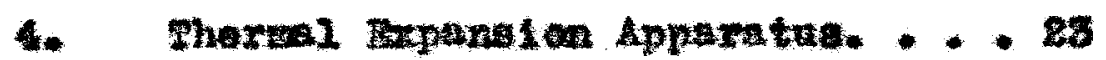

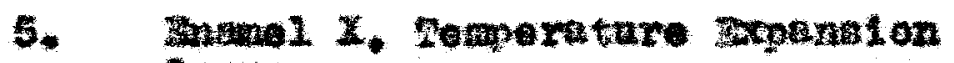

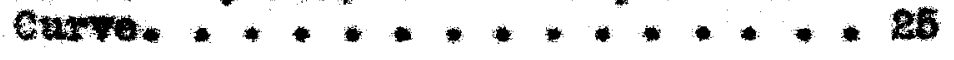

6. Orohlend Keprogentation of Bata $\ldots \ldots+\cdots+\cdots \cdots+\cdots$ 


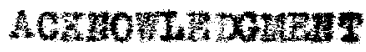


Ir

The Eathor wishes to express his

sincere sppreotation to Dr. H. E. Carewell

for his generous aseistance in the preptretion of this thesie. 


\section{marovUcrion}




\section{Introptestow}

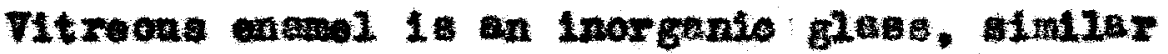
to the glase used in miking windowe or bottles, and la often onlled porceisin onama to distinguich it from organlo palnt enmels. The dosignation, vitroons onaral. Is most genersily agaociated Uth opagne glaso costinge on mol. although applyine equelly well to opaque glazes nsed on pottery. The asatim tions botren glass, glaxes, and ondals are Ia ase and apliestion. not in propartios.

The constitution of gass heo been and et121 is the sabjoct of conaldarablo controveray. One hypothesis

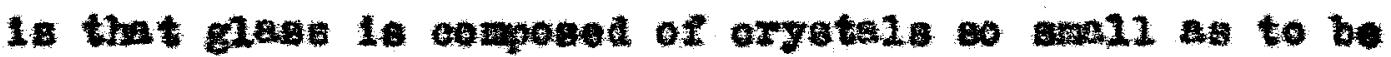

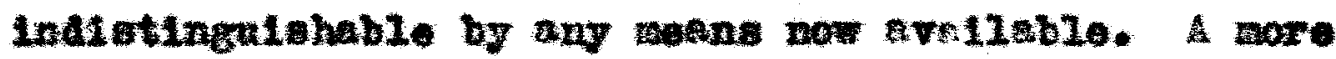
generally acompted thoory ia that mioh destgnetos glase an andereooled 21quld (1). The bosis of this theory

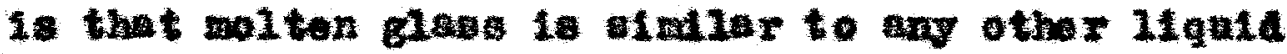

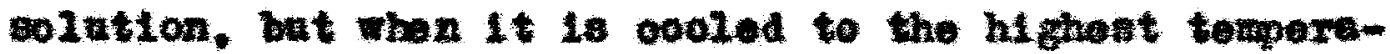
ture thich one of Ite componente worla tend to

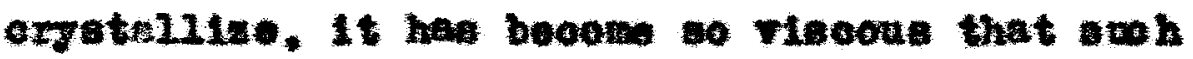
aryetallisation io imposible.

one of the charweteristle propertios of gase 10 thet it has no woll defined ting polnt, nor does it whos any definite break in host ofpecity at or near the 
goftening point. at co orytatiline enbetances. Whan wol ten gas: is cooled it grodnaly boconos more viscons

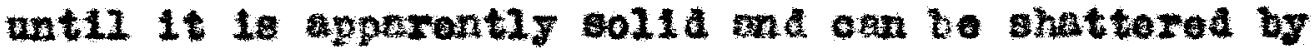
adden Dechantcal gtrese. Horever at thie polnt and for an appreciable tempextuse range domman, the glase may be permently deformed by otroas alowly applied over a oufleient perlod of tine. This temperature range for any partiouler glass is collod its annealing range, where internal etrains will ajuat thewselves providing the time Is ouffolont. Theoretiobily the anneal ins range has no lower limt. bat In proctice the 11 necessary for roleve of otrain inoreases so raplaly with deorenoe in

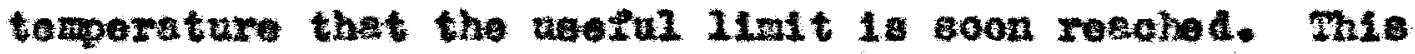
Ilat 10 of conslareble importance in the appliestion of encmels to metel. since at all low or temperatures the enomel mat respond almonelonaly to temperature very nearig the base se does the petal to which it is bonded. This roswte trom the frot that al vitroous entwoling proevs:es involvo fating partial of of onduel in contaet Wh the tal at temperateroe well abore the annening range. While oooling, the onamel will deform in aecordeneo wth any afferential sluxinkage of the wetal, watil the Iower temperature ilmt of the ameding range if recohed. If at this point the enasol is ahrining wore raplaly than 
the tel. Ane oreek w111 ocour. Fis is collea erazing. If the entemel shrink iose rapldy than the motal the resultant compresalon way become so groat that pleces of the conting break 2000 , partienis riy at odges and convex surfoces, This reoult is onlled onipping.

Then the thermal expansion and contraction of onamel and motal tre in anch cloe agroenent that chippir:

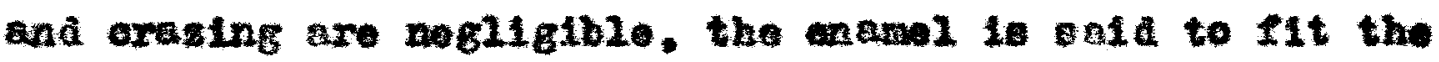
wotal. The neoesalty for control of this fit has been

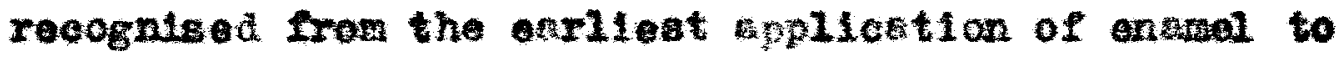
motal, but often without any oonoeption of the principles involved. It wag known thet inoressing a ootain rew matial in the ensmel tended to stop oreztre, and decreasing it wovld stop ohipping. vith a afferent raw weterial the roverte might be true. Such empirioal wethods of control were in we witil compratively recont times, when the avnulbility of rew materials of standard and valform compaition, and the repiday expanding use of

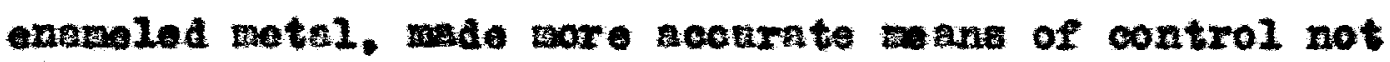
only posalble but essential. 
HISTORICAT 


\section{HISFORICA}

The flret Eytantic Invertigetion of the

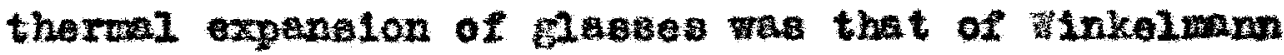
and sohott (2). They rowd that the physienl propertien

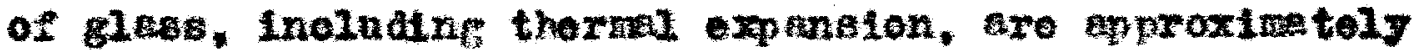
adaltre in proportion to the relative tuounts of the component oxldes. After an axtengive invertigation theg wore ble to expross helr raoulte in terms of axile factore. en petor repreanting the effect of one per cont of the partioular arie. In ardar to ouloulate the coefilclart of thorad expension of a elate. the motor fox ach oxldo was mitipllad by tho nex oont of that oxlde in the glaso and the reaul gdded together. They called attantion to tho fhet that euch robalta sre only approxidatoly corrat and thet the fatore chom apply only to the renge of compositione within when they worked.

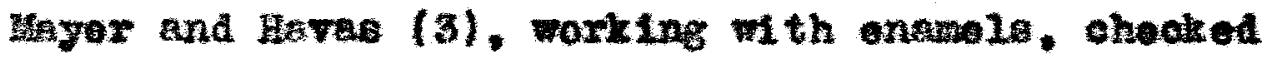

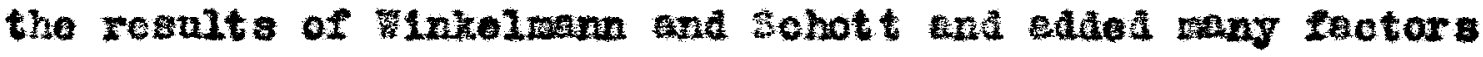
not Included in the original investigetion. Genlhote and Thowa (4) working th glasese, polnted out thet any set of oxide factor is acourate for only a lintbed flela of

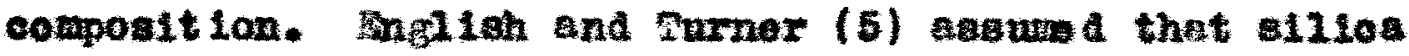
oarrios the thermal oxpansion of fued quarty lnto gase 
and on this bsis deteralned a sot of exide factora that Show an apreolablo ceperture fron thoes prevlous $1 \mathrm{y}$ derived. Thelr resulte indicate that boron oxide does not five the addifive mue chnrecterietlo of the other axties, but that orar cortain ringe 1 te effoct decreases to sinimu and thon inoreases agein. Thog found further

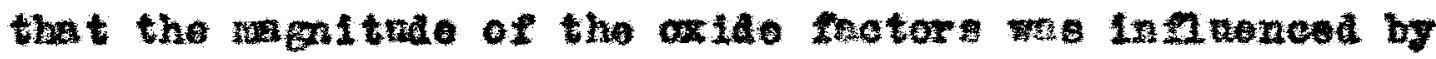
the composition of tho glass and ophastised tho thot that they worked in the comparatively narron toporature range of $25^{\circ} \mathrm{C}$ to $90^{\circ} \mathrm{C}$. Fetteroif and parmae $(6)$ wantig the

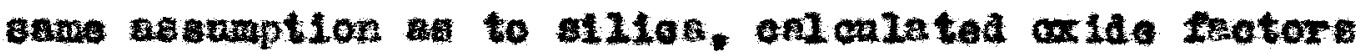

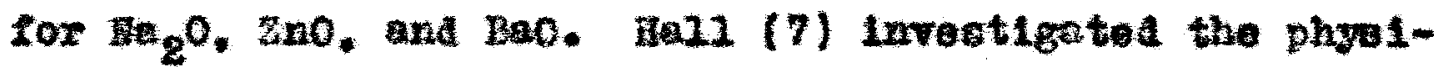

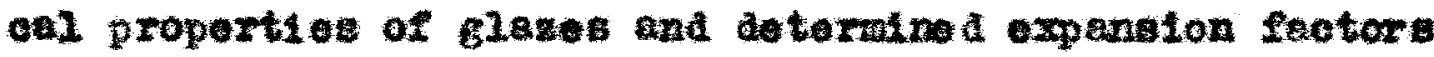
for veveral oxides.

Andrews and sath (8) datormined the coefficiente

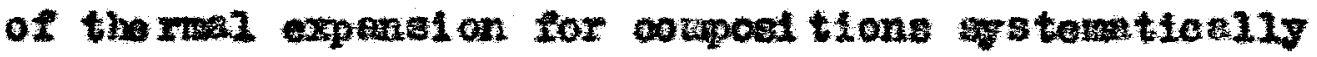
rarled throngh the flela of sheat iron ground cont onawels.

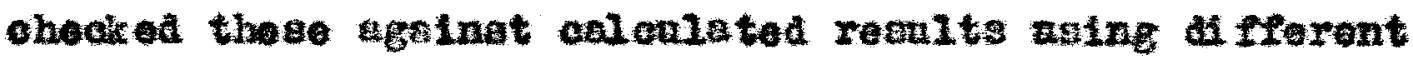
sets of oxile factors. and coneluded that the fsotors of Wayer and havas are wot acourate for this type of onabel. In a later paper. Andress and flowe (9) conoluded that the coefflolent of tharmal expansion of aheot iron cover cont ennels opnot bo celoulated acourately from any previonsiy determined set of oxide fetors al thougt thoee 
of Hayer and Have were woat nearly appllonblo. Thoy showed that the error mey heve been atue in part to the high flnoride content of opeh enamels. Zinzio and Comeno (10) compared regults obtalned by differant wothods of monending the coeffrotent of thernel expansion of cnessels wh thesurements of the ohipping tendenoles of tho asuo onamels, and conolnded thet other propertles than the exptess ion ware of laportanos in dotoraining the $12 t$.

It aedes ovident from the refarenos clted that

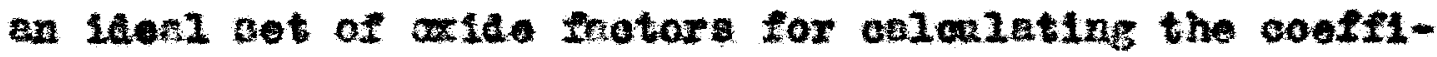

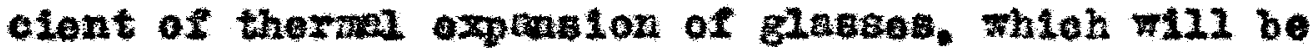
socurate for all terperature and compostion ranges. does not exiat. In nonrly ovary irvestigtion a otatowent is ade that the Andings apply only to the apeelfie reage of comositions stadied.

The orrller investigetors deteralned the rmal

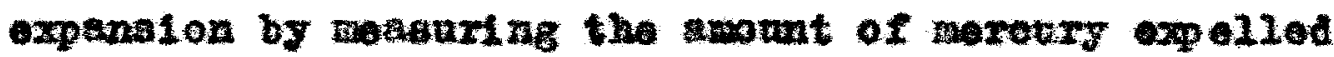
from alb of the ala compost tion being teated. whon tho temperature wa lneronsed throngs aefinito interval.

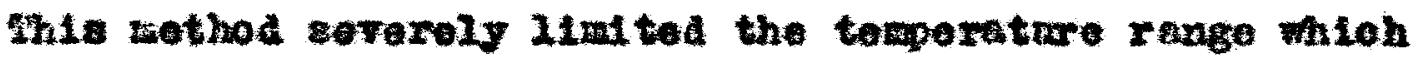
pansily ald not extena bove $100^{\circ} \mathrm{C}$. Hore reeent workers In this fiela, overeoming temperaturo $21 \mathrm{~m}$ tations with Improved athods, hare conflned their experiwents to 
roletively olmolo glaber, or ele have cheoked noarured expan lono with onlcnlated resulte obtalned by using one or more of the prodeternined seta of oxtde factors. There numer of oxide fotors have been deternined, the wethod exployed ha bean to subetitute gucoessively definite quantitles of beveral alferent oxides for equivelont quentity of one of the oomponents of simple Blake. Howing the oxide faotor of the roplaced component, and the coefficients of thernal expanaion of the two ginsaes, it whe poselble to odenate the axide feotor of the roplacing axide. snch values nuy not be accurate for the name oxides coexistant in a cospiex gluse.

The field of dry prooeds enabels for oset fron has been rather neglected in thernal expens ion investigetions.

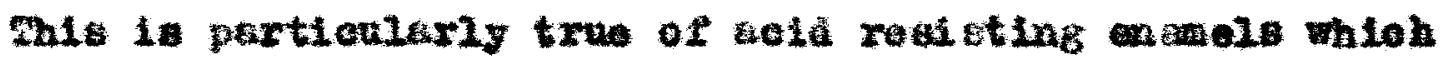
have been developed largely in reoent yours. While the verious ete of oxide factor have been found very neeful in working with suoh ondrals. inscouracies are often notod. Por inetance. In working in th two different typer of ondels, both having a atiafactory fit to the seme wal base. the enleviated coefficients of theral expens lon ay show pronouncod af eferanee. It lo evident that the Ectud coefficlents met be very nenriy the came. 
Consideration of awh occurrenees, together with the afecusation in the previons peragreph, lest to the conclasion thet in invectigation in the field of ary procese aold reelsting enals for enst iron bhond

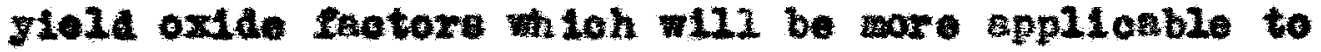
ench conpostione than any avaliable from previone investlgations. 


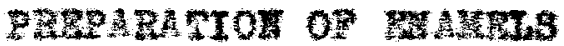

And nes 2008 


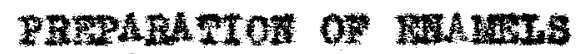

AnD rase

In order to narrow the fleld, the bato onomel oomporition was livited to the Ingmedients whioh exportenee heis proved to be both nocesedry and suffialont for the production of a satiafoctory ada

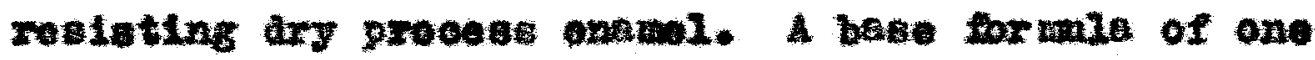
hundred perte we used, woportioned enong the aifferent ingrodiente that a varistion of from thres parts 108 s to three parts wore for each ingredient csrried it through the renge in wioh it normaly ocenro In enth compost 10ne. A further consideration was thet rarlatione of this tagaltude ehowle not eppreolably alter the type of the reeulting oname

The enersel cospositlons nsed in these test are chown in rablo 1, the baste anal compoltion belng

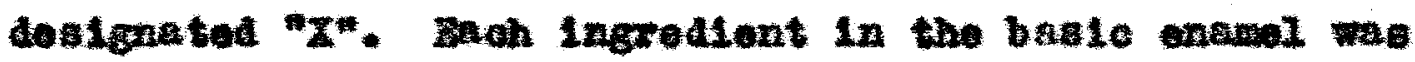
varied in turn, frow hree parth loes to three parte wore then 1 te proportion theroln. This variation was belleved to be the waxim wheh cowa be aed without dangex of oltering too groatly the onbmel oharacteriatioe, won appliod to thoes ingredients whioh ocons in relatively 4anention.

Comeroial raw materials wero abed in preparine 


\section{Table 1}

Compostion

$\begin{array}{lllllllll}\mathbf{X} & \mathrm{Al} & \mathrm{AZ} & \mathrm{BL} & \mathrm{B} 2 & \mathrm{CL} & \mathrm{C2} & \mathrm{DL} & \mathrm{D2}\end{array}$

$310_{2}$

$\mathrm{niO}_{2}$

$\mathrm{B}_{2} \mathrm{O}_{3}$

$\operatorname{ma}_{2} \mathrm{O}$

Pbo

coo

${ }^{313} 6$

$\mathrm{sb}_{2} \mathrm{O}_{3}$

$810_{2}$

$\mathrm{NO}_{2}$

$\mathrm{B}_{2} \mathrm{O}_{3}$

$\mathrm{Fa}_{2} \mathrm{O}$

Pbo

ceo

$\mathrm{Ha}_{2} \mathrm{sin}_{6}$

$\mathrm{sb}_{2} \mathrm{O}_{3}$ $\begin{array}{lllllllll}40 & 37 & 43 & 40 & 40 & 40 & 40 & 40 & 40\end{array}$

$\begin{array}{lllllllll}6 & 6 & 6 & 3 & 9 & 6 & 6 & 6 & 6\end{array}$

$\begin{array}{lllllllll}6 & 6 & 6 & 6 & 6 & \underline{3} & 9 & 6 & 6\end{array}$

$\begin{array}{lllllllll}15 & 15 & 15 & 15 & 15 & 15 & 25 & 12 & 18\end{array}$

$\begin{array}{lllllllll}25 & 15 & 15 & 15 & 15 & 16 & 15 & 16 & 15\end{array}$

$\begin{array}{lllllllll}6 & 6 & 6 & 6 & 6 & 6 & 6 & 6 & 6\end{array}$

$\begin{array}{lllllllll}6 & 6 & 6 & 6 & 6 & 6 & 6 & 6 & 6\end{array}$

$\begin{array}{lllllllll}6 & 6 & 6 & 6 & 6 & 6 & 6 & 6 & 6\end{array}$

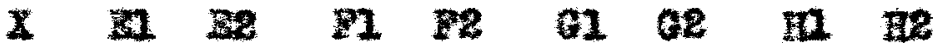
$\begin{array}{lllllllll}40 & 40 & 40 & 40 & 40 & 40 & 40 & 40 & 40\end{array}$

$\begin{array}{lllllllll}6 & 6 & 6 & 6 & 6 & 6 & 6 & 6 & 6\end{array}$

$666666 b^{6} 66^{6} 66^{6}$

$\begin{array}{lllllllll}15 & 15 & 15 & 15 & 15 & 15 & 15 & 15 & 15\end{array}$

$\begin{array}{lllllllll}15 & 12 & 18 & 15 & 15 & 15 & 15 & 15 & 15\end{array}$

$\begin{array}{lllllllll}6 & 6 & 6 & 3 & 2 & 6 & 6 & 6 & 6\end{array}$

$\begin{array}{lllllllll}6 & 6 & 6 & 6 & 6 & 3 & 9 & 6 & 6\end{array}$

$\begin{array}{lllllllll}6 & 6 & 6 & 6 & 6 & 6 & 6 & 3 & 2\end{array}$

Vartatione from bakio compos tion ere underlinod. Formalse are not in per cont except for " $\mathrm{X}$ ". A1. Bl, ato. have 97 parte. A2, B2, oto. have 103 parta. 
the eamels. Fith the excoptions notod later. their parity 18 not leas then $99 y^{*}$. It 18 tenown the tome of the terials need have apprectable veor proseure at the temperatures used in wating eremele. Phis reealte in a sall bat definite decresse in the proportion of these matorial as suppliod by the rew batoh. Soda Aah $\left(\mathrm{Fa}_{2} \mathrm{CO}_{3}\right)$ is al ightly hygroscopto. The soda wo nod in propering these onowels whe arled in an encloed, ventilated oven for three hore at $150^{\circ} \mathrm{C}$, and allowed to cool to roor temertive before welghing.

Boron oride was introdneed in the for of cownorelal anhydrons borax. It Is belleved to be lese volat1le in this form then when added no compona contalning combined wer, and there is certainiy leas moohale:2 1006. Sinoe anhyarous borax vartec alightly from the theoretion compostion, the lot need for this work wae thoroughy wixod and a representativo anuplo enal yeed. The aner jols ahowe. $\mathrm{B}_{2} \mathrm{O}_{3} 65.89 \%,{ }_{2} \mathrm{O} 31.73 \%$, and an lenition 1008 of $2.34 \%$.

sodin Fuovilleate, when heated by itself. decompeses into eod an Anoride ond voletile slileon totrefluoride at tomeraturea lower than those rokenod In onelting onanel. There bey be reactions within the melting enamel batch which tend to 21 mit the lose of 
allicon tetrannoride: aliee it is knom thet the effect of sodum nuovilleste upon the propertios of en onsmel. when compared to wore stable huoriden oneh es cryollte and fluorepax, is groter than would be apperant on the busis of 1ta sodilu huorlde content ondy.

Antinony oxide gives the onamel opacity. It is oupplied the relatively volatilo trioxide and requires addition of adine altrate to the batoh to caldie 1 to the penteralent forn toh is steble. Thooretionily a Alaperae phese in alase hould have no effect on 1 te

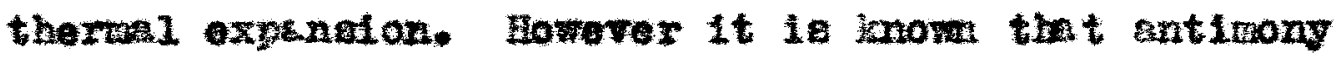
oxide has a very dorinite offect. Thether this result from combinstion with other ingrediente of the entwel. or from partini solution, or both, is not tenown.

It is evident tron the foregoing conalderations in regerd to rew terials that a prooleo determination of oxide fnetore for any of the phyeienl properties of an enamel wond roqulre a coplete and becurato quantitetive

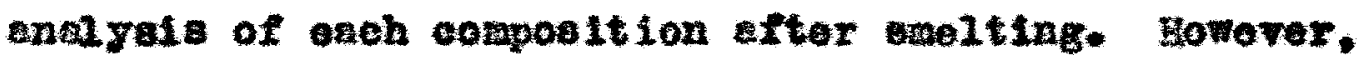
since the parpose of this imeotigation is to determine

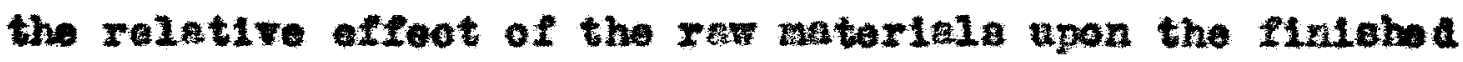

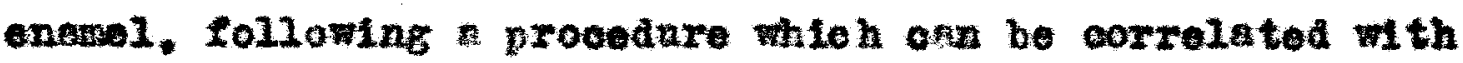
that obtaining in the proparation of comerelel enamola. 
euch candyea wero not sade. The only stipulation in reopect to the fintshed enselo is that their phyoleal propertien shall have defint to and unflorm ralationehip to the proportions of raw werlals and. The row material compositione of the entals prepsrod for this Investigation are ghown in Sable 2.

\section{Preparation of Primale}

The batches of res matertal wore proportioned to give anculated welght of 1000 grast hen woltod. Beoh matertal was wel ghed to the nesrent $1 / 10$ of arata. The wolghed batch wag acreaned though twenty wah oleve to Inevre the absene of lumpe, and thoroughly aixed. Three botohes were mate of the 10 anemel composition and two of exch of the others. The enowels were smelted in a

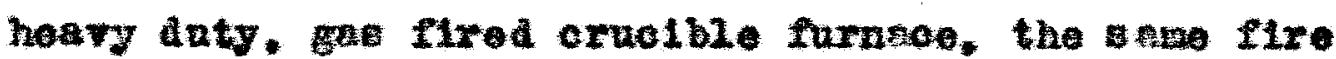
clay cruotble boing ueed throughout. A leede and Wor thrup optloel pyromoter wee used in controlling the tomperature which whe held at $1095^{\circ} \mathrm{C},\left(2000^{\circ} \mathrm{M}\right)$. Seah betoh of enomel wa alowod to molt unt1l evolution of we hed cessed. It wes then stlrred thoroughly ith an lron rod of auf fle lent welght to provent its beomine hot enough to seale and contriningte the enamel. After five minutes the stirring 
$\operatorname{men} 2$

Raw teris corposition

$\mathbf{z}$

\begin{tabular}{|c|c|c|c|c|c|}
\hline${ }^{510_{2}}$ & 40.00 & $\mathbf{2} 1$ & 37.00 & $A 8$ & 43.00 \\
\hline $\mathrm{FiO}_{2}$ & 6.00 & B1 & 3.00 & $B 2$ & 9.00 \\
\hline${ }^{\mathrm{Na}_{2}} \mathrm{~B}_{4} \mathrm{O}_{7}$ & 9.11 & c1 & 4.55 & $\mathrm{c}_{2}$ & 23.66 \\
\hline Zarro $_{3}$ & 6.00 & & & & \\
\hline \multirow[t]{2}{*}{$\mathrm{ga}_{2} \mathrm{CO}_{3}$} & 27.68 & $c 1$ & $20.05^{\mathrm{z}}$ & $\mathrm{c2}$ & $16.11^{\mathrm{a}}$ \\
\hline & & m. & 12.45 & $\mathrm{DE}$ & 22.70 \\
\hline $\mathrm{Pbo}$ & 25.00 & $\mathbf{n}$ & 12.00 & 32 & 18.00 \\
\hline $\mathrm{CacO}_{3}$ & 10.71 & $n$ & 5.35 & P2 & 16.06 \\
\hline${ }^{*} a_{e^{3 L}}$ & 6.00 & 02 & 3.00 & 92 & 9.00 \\
\hline $\mathrm{Sb}_{2} \mathrm{O}_{3}$ & 6.00 & $\mathrm{~m}$ & 3.00 & 12 & 9.00 \\
\hline
\end{tabular}

aa. 3odn agh warked to compensato for changes in walem oxide content esusea by vexylng borax.

The compostion of eneral $X$ is Given complotely. The other compestione affer fro onamal $X$ only in rospeat to the meterials for whioh the mounta are ghown. 
wa roposted and sfter onother fire sinutes the bateh was quanched by pouring it into cold water. The first two batehos of the bsele onamal $(X)$ were need to rinoe and glase the oructble, ha alsended after staltirs. The first bateh of ofoh of the other manela was uned as a rines batoh to Inewre agefnet orrxy over trom one

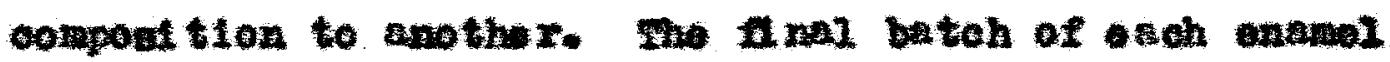
was geonchod and then dried in en enclooed oven.

\section{Prepextition of saples}

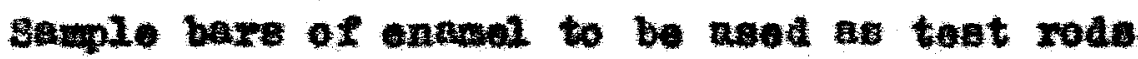
ware prepared in mohne pressed, trough ahaped, shoet

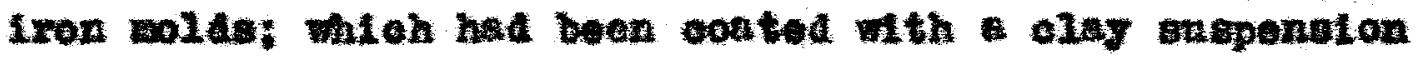
to prevent the ondmol from atiaking whon hoted.

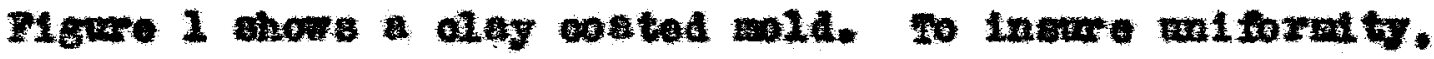

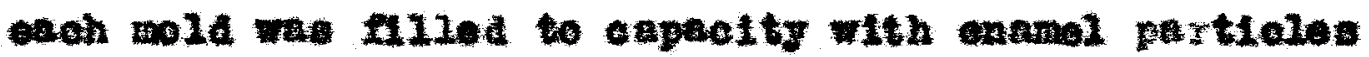
wioh had passed a twenty woeh steve. In order to pormontly laentity oach test rod vory all portion of affrorently colcred anam pewdore were epplited to the onftroe of the onamel beged in the mold. In the soberquent troktmont colored lote wre forme on the atertace of the roill.

The molate Fhieh contrine enderel were heated in 
इ⿻上丨า 1

Hold Ior Mest Rode

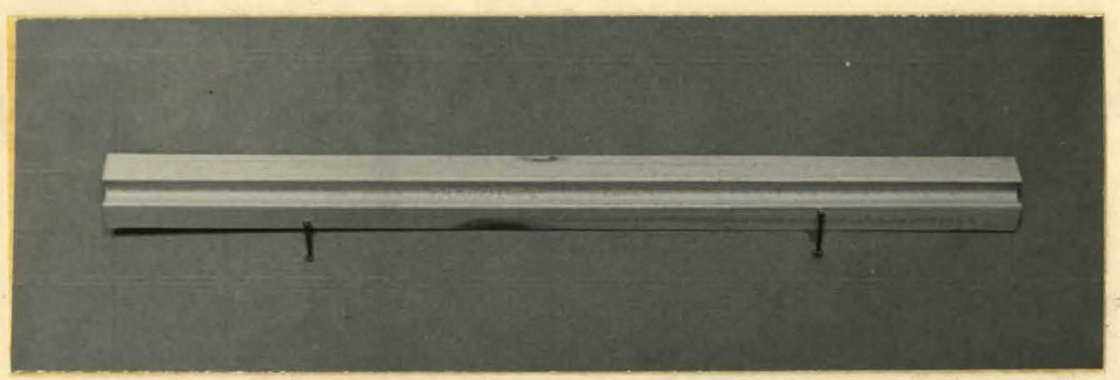


an electrio furmece to a tampersture of $675^{\circ} \mathrm{C}$ which was enffictent to fuse the ennuel. The furnace was then shut oft and allowed to oool. Due to hatry Insulation the cooling rete was sow anough to lnaure getibfactory annealing of the rods. After cooling they separnted easily trom the nolds. The finiahe teat rods wore seven and one half inched long snd about three sixteonthe of an lnoh In alnmoter. one and of eseh was ground on an abrastre theel to a homispherieal ahape. The other ond wee notehed and broken to wate the length of the rod epproximately geven inohe. This ond

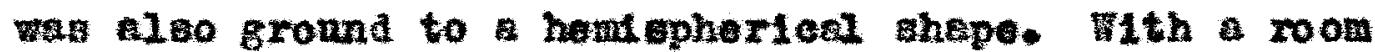
tempereture of $70^{\circ} \mathrm{z}$ the lexsth of exch test rod was doternitned to the neareet ton thoueandth of on tnoh by reans of mierometer callper ad lbrated to rend correctiy at thet tomerature. These lengthe were recordod in the ata. 
A gpararus 


\section{APRARATUS}

Thermel expnation meatrer eranta Fere made by mans of allotonteter. This Instrusiont consists essent1 21 y of fused guarta onter tube thich has one ond closed, and a chorter lnner tabe of the same beteribl. closed at both ends. An Amo Dial calibrated in ton thonesnath of pn inoh difisions was clamed to the open end of the outer tube fith its apendex centered in the end of the tube.

A hesvilg ingulated. vertion eleotric trabe furnece was need for neating the allatometer. the rate of texpersture Inorenge belng controliad by a rhoostat. in Iron-constantsn thernooouple and toods and Jorthrup

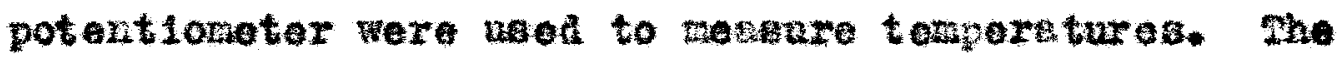
thermocouple was made from $22 \mathrm{Bg}$ gafo wire, and wen

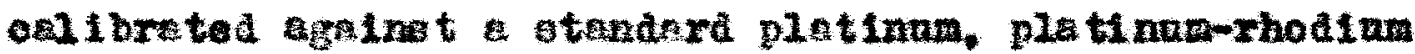
couple, wa fond to have negligtole deviation from

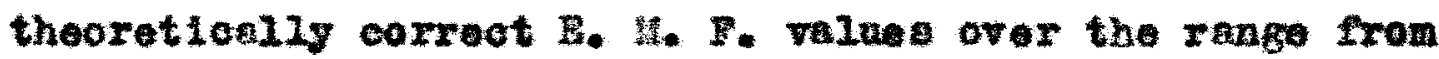
$200^{\circ} \mathrm{C}$ to $500^{\circ} \mathrm{C}$. A recent paper by indicating that a therrocouplo of this type will have no elgnifloant changes in it B chnrecteris tios for tempereture ranges and durations oquivalent to thoes ued in these teats. A mercury in glaes Inborstory thermoter wo ued 
to meneture cola junotion temperatures.

Bino the diffeter of the toet rods we grall

comprred to the dinmeter of the outer allatonoter tube.

1t was nocesary to aupport then in the corroct

conial postion. A eupport was for frod stalniesa ateel and oo constroted that the rod fnd anport could expand and contract independently. 
E MOODDUES 
The junotion end of the thermoconple we contednad within a theo litoh porcelnin inenlator, wh the tip of the junction profecting aligitiy. It was fastened to the chamal rod to be tested by wasto of a "1re wped a rotud the Insulator snd rod. The al ignwent was and that the tip of the thornocouple jwnetion was at the center of the tent rod. The rod with at tecsed the rnocouple wa placed in the seinleas steel aupport as ahown in Pizure 2. This cominntion wae insertod in the outer dilatometor tabe so that the lower and of the test rod reated nget not the closed ond of the tube. The inner dilatometer tube mss then placed wthin the onter tabe with fte lower ond in contaot with the npper ond of the test rod and 1 ts upper ond Just within the open ond of the outer tabe. The thermocouple wres were posit lonet betwoen the tubes in a rumer to prevent an smeldental short olroult, and to allow froe wovent of the inner tube. Plgare 3 111ustrated the aveerbiy at this otage. the dilatometer sasembiy wo then pleced in tho vertical tube furmaco and apcured th adjosting ecrews at the top of the Armane. The Ame Dial we aljusted so thet ite eppendix rested sgainst the top of the inner allatomter tebe with auficient pressure to rotate the indicnting 
needie through ten to twenty divielons. Conelderation of this atombly wates it obriong the the expanation of querta noed bo taken lato aeount for only that length of tribe occupled by the gample rod. alne the expansians of the two allatometer tabes wero sell compenosting above the rod.

The thernoouple wires, whieh had been mede $10 x \mathrm{~B}$ enough to elinanate the nocesity for auplewentary lesds. were connected to the potentlometer. The zero setting of the latter was adneted, the cold junction texperature rend trom the adpoent thermoter, and the cold junotion compensetor set cecoraingly. The anibrated race of the

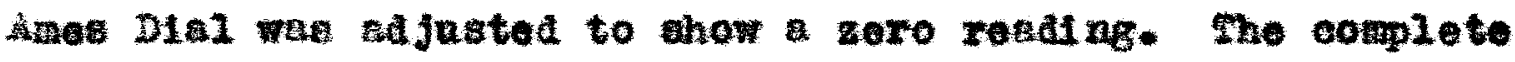
exponeion apparatue 18 hom in migare 4

the furnsce was aterted and the expandion road and recorded at intervel of $60^{\circ} \mathrm{p}$, from $100^{\circ}$ to $760^{\circ} \mathrm{p}$ inal neive. The nae of the Bagliah longth wit and the Fahrenhelt temersture eonle was das to the onlibration of the dilatometer and to the aveliability of printed data shoots incorporating the orrection factore for the oxponstan of quartz in these wita. Fodor the olroumatmonos it was atreplor to proceed wh these wite and onlonlate the results to the metrie equivionta.

The rato of temperature inoresse was held ae nearly 


\section{Mgure 2}

Foat Hod and Support

Thormoconple Atteched to rod

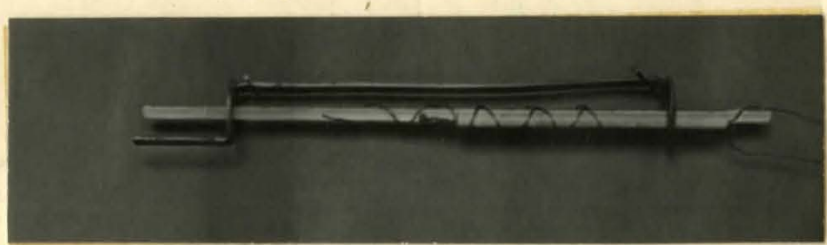

B1 gure 3

B1.latomoter Assombly

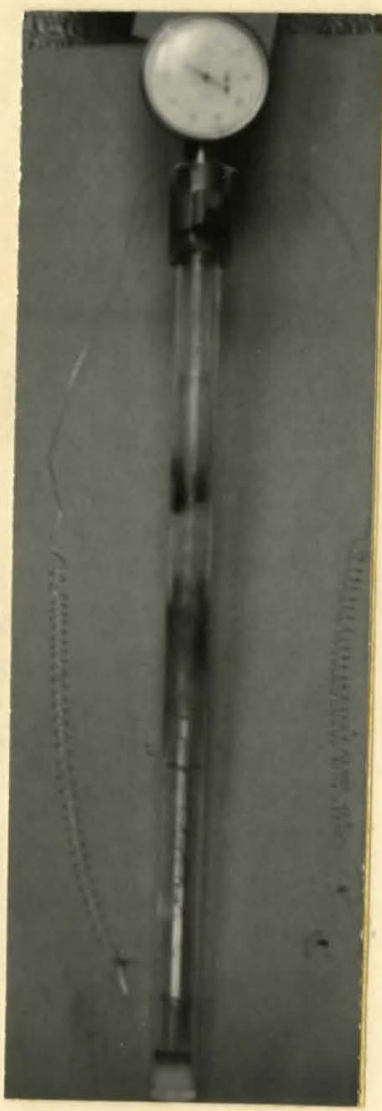


P1 grare 4

Therral Bxpansion Apparetus

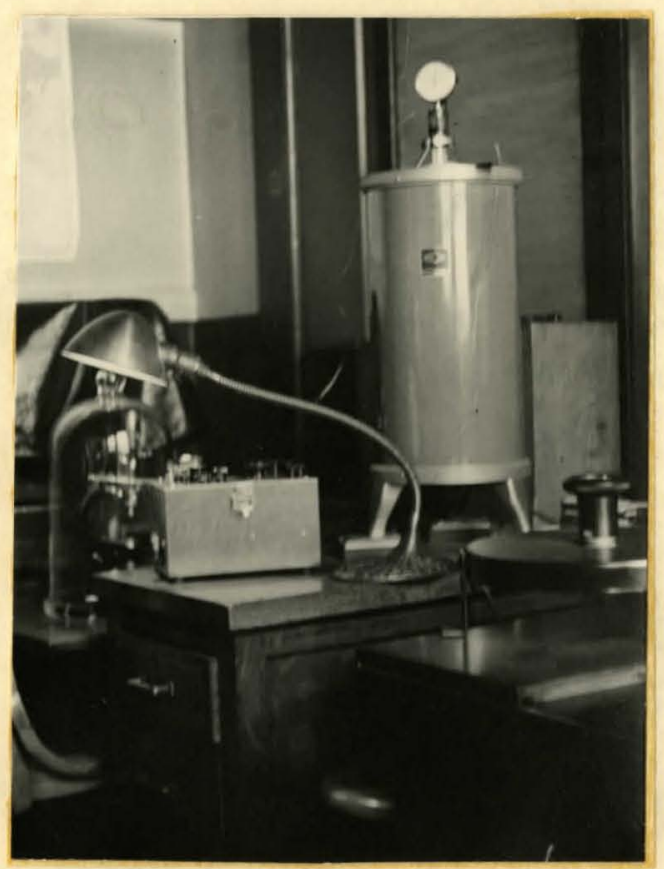

Dilatoneter and Furnoce townd the Reax Potent1oneter, Front LePt vndor Desk Lamp Rheostat, Front Right (only partly showing) 
a. posalblo to $50^{\circ} \mathrm{F}$ in el ght minutes. by rheostat regulation. This rate was elected bookse it is appreciable lower than the alostole rete of toperatme deoreace rocomended for anenling finge of thleknets corresponding to thet of the rods. An analogy was drexn from the neceseity tor having nealisible terapersture gredient through the botion in each case.

The lamer temereture 11 mt of $100^{\circ} \mathrm{F}$ we pelected to be ebove the maxtrata room tesperature likely to be encountered. The upper temperature 11 xist of $750^{\circ} \mathrm{z}$ was based on conat deration of the complote temperntire experse ion curve 111ustrsted in 1zwe 5. showing the expand ion of hamel I tron $100^{\circ}$ I to tho estening point at $915^{\circ}$. It w111 be noted thet the rate of opansion increased rather uniformy to point about $75^{\circ}$ below the softening point there it beokso nuch wore rnpld. This type of enrvo is charseteristic of glacses end it it wthin the renge of rapld expanaton that annealing teices plnoe. Dno to tho foct that internal Btraina are sels adjuating in this range it whowd bo excludod from dsta

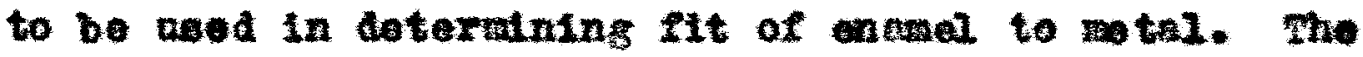
$760^{\circ}$ Ilalt was belleved to be sofely bel ow any hifts In the enresitig range which of ocour in the serles of onamel compos itions tested. 


\section{Es gnxo 5}

Fnamel X. Corylete Eoryereture Bxpension Curvo

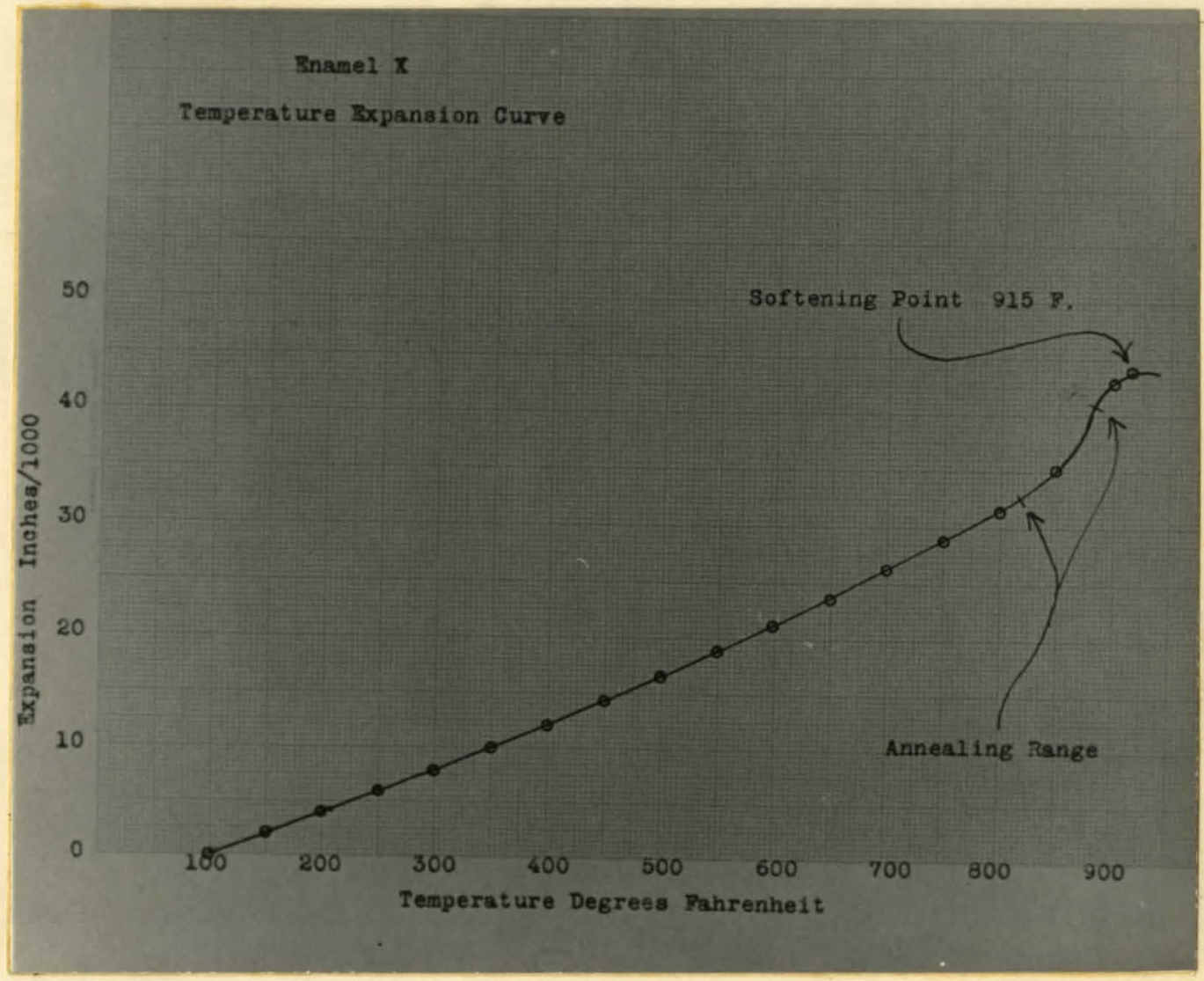


Bxpansion doterminations wer te ducosaively on the serles of test rode representans the different

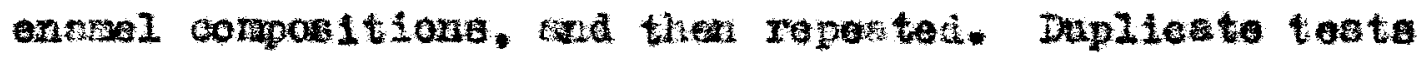

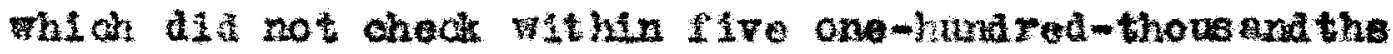
of su inoh for the tesperature laterval. $100^{\circ}$ at to $500^{\circ}$. ware repested thira tide. In oraer to avold repetition

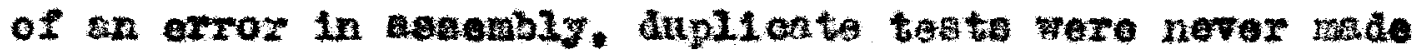
suecesditely on the ame antule. 
SOURCBS ON BREOR 
SOURCES OP RREOR

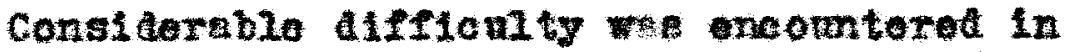
arringthe the therwoconplo wire so that they would not interfere wh the froe movenent of the inner allatonotor tabe. The latter its $200801 y$ with the onter tube in order to allow alearance for the wires. and if the assembly mo not guite right. difforential expansion of these wireo during the expandion deteraination caved ellght shifting of the inner tube

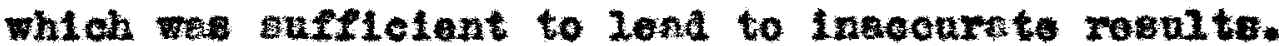
In 1t of every care used in ssombly. this ooourence could not be positively prevented, and is bol leved to account for toet of the uneatiefactory doterninations. The equivane of Thermoonple zotential. Fempersture. Ane thermel Expansion are rovghly in the ratio of 1.5 sillivolta to $60^{\circ}$ to 20 Fen-thonesnd the of sn lnoh. Expanelion roedinge were wade to tho nosrest one hale Boalo Aivigion on the Nas Dial, that 16, to the nesrest ifve one-hundred-thowesndthe of an inah expenalon. Settinge on the poten tlometer cold junction compenator. and on the lower tempereture soelo. $0^{\circ}$ to $500^{\circ} \mathrm{F}$, were cocurn te to rithin plus or sinus 0.01 milifvalt. and on the upper temperature sonle, $560^{\circ}$ and abov, to Fithin pline or minus 0.02 millirolt. A posalble error of plwa 
of minus 0.03 wilitrolt cond have reeuted from those

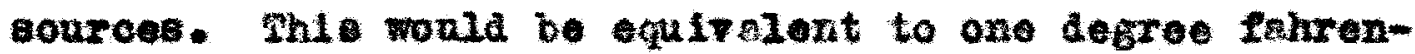
ne 1 or to one thira of ten-thousandth of an lnch expantion. Broeptional care used in araing the settings for the elret and Inal expansion rodalne, upon which the onlonlatione were baged. ghond have rodnced the arror wth respect to these radinga.

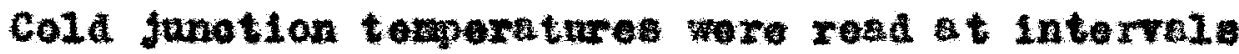
auring each test and the compansator reat 1 neceasary.

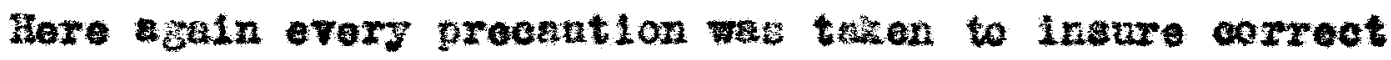
settings for the firet and Innt refdings of osoh run. srrors in comnestion wh onowal batoh compositions here been discusued provionaly. It 10 balieved thet oonoldertion of the detr 111 apport the conoluston that the souroes of error enumarstad aro ouficiont to acoont for suoh alsorepaneles as extat. 
DAz 
DAW

The Ager Dinl was at at zero for the start of exch rum. Slnce the initing turnace teraporatue differed for the different rwa, the tempreture intervis ap to the firct resaing at $100^{\circ} \mathrm{F}$ variea conalderably, and the recorded rendinge fot this temperature varied accordingly. It vill bo obcerved that numeriod vel ned of apeofflo reatings are whinportant, at noe only the interrals between the firt end final ropinge have algnifleano. Theretore. in order to Inell1tate cotararison of the expunston rans. the data were corrected to initiel resdings of gero at $100^{\circ}$. Table 3 inaludea all thorwal expanaion dats. Figure 6 is a graphical reprosentation of the effeot on the thermal expanoion of zanael $x$ when eceh rew torind is varied in tarn, the ourves having boen derived frow the deta in rable 3. Sol1a 11 nes represent the expansion of enosals contelning three parts less of the teris ahow than 18 contained in Bnewel $x$. Broken Iines represent the expansion of enawels containine three perte more. The degree of eparation of the ilned represents the mitude of the effect on expension, while their reletive position shows its dreation. 
Fable 3

Date

Brpention Inehas/1000

\begin{tabular}{|c|c|c|c|c|c|c|}
\hline $\begin{array}{l}\text { Teat Rot } \\
\text { Leneth }\end{array}$ & & $\begin{array}{c}x \\
6.996 \\
\end{array}$ & & & 6.995 & \\
\hline ISpa too & 1 & 2 & 3 & $I$ & E & 3 \\
\hline $\begin{array}{l}0 m p \cdot{ }^{\circ} . \\
00 \\
50 \\
00 \\
50 \\
00 \\
50 \\
00 \\
60 \\
00 \\
50 \\
00 \\
50 \\
00\end{array}$ & $\begin{array}{r}0.00 \\
1.80 \\
3.90 \\
5.90 \\
7.90 \\
9.75 \\
11.05 \\
14.00 \\
16.30 \\
18.55 \\
20.95 \\
23.45 \\
25.95 \\
28.50\end{array}$ & $\begin{array}{r}0.00 \\
1.80 \\
3.80 \\
5.85 \\
7.80 \\
9.80 \\
11.90 \\
14.05 \\
16.35 \\
18.60 \\
21.10 \\
23.55 \\
25.95 \\
28.56\end{array}$ & $\begin{array}{r}0.00 \\
1.80 \\
3.80 \\
5.86 \\
7.75 \\
9.80 \\
11.90 \\
14.00 \\
16.30 \\
18.46 \\
21.00 \\
25.60 \\
25.85 \\
28.50\end{array}$ & $\begin{array}{r}0.00 \\
1.85 \\
3.96 \\
5.95 \\
7.95 \\
9.90 \\
12.05 \\
14.25 \\
16.55 \\
18.95 \\
21.45 \\
24.05 \\
26.65 \\
29.15\end{array}$ & $\begin{array}{r}0.00 \\
1.85 \\
3.90 \\
5.90 \\
7.85 \\
10.00 \\
12.05 \\
14.30 \\
16.00 \\
18.95 \\
21.50 \\
24.00 \\
26.55 \\
29.30\end{array}$ & $\begin{array}{r}0.00 \\
1.85 \\
3.90 \\
6.00 \\
7.90 \\
10.00 \\
12.10 \\
14.30 \\
16.60 \\
19.00 \\
21.55 \\
24.05 \\
26.60 \\
29.30\end{array}$ \\
\hline
\end{tabular}

\begin{tabular}{|c|c|c|c|c|c|}
\hline $\begin{array}{l}\text { coot } 200 \\
\text { length in }\end{array}$ & 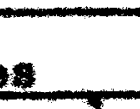 & .026 & & 7.027 & \\
\hline $\mathrm{an} \mathrm{Ke}$ & \pm & 2 & 1 & 2 & 3 \\
\hline $\begin{array}{l}10 m p=0 \\
100 \\
150 \\
200 \\
250 \\
300 \\
360 \\
400 \\
450 \\
600 \\
650 \\
600 \\
650 \\
700 \\
750\end{array}$ & $\begin{array}{r}0.00 \\
1.70 \\
3.65 \\
5.65 \\
7.45 \\
9.45 \\
11.45 \\
13.60 \\
16.80 \\
17.95 \\
20.35 \\
22.85 \\
26.15 \\
27.80\end{array}$ & $\begin{array}{r}0.00 \\
1.75 \\
3.75 \\
5.60 \\
7.60 \\
9.50 \\
11.55 \\
13.65 \\
15.90 \\
17.95 \\
20.46 \\
22.95 \\
26.20 \\
27.00\end{array}$ & $\begin{array}{r}0.00 \\
1.80 \\
8.85 \\
5.90 \\
7.85 \\
9.85 \\
11.95 \\
14.10 \\
16.50 \\
18.90 \\
21.35 \\
28.80 \\
26.40 \\
28.95\end{array}$ & $\begin{array}{r}0.00 \\
1.85 \\
3.90 \\
5.90 \\
7.90 \\
9.90 \\
12.05 \\
14.25 \\
16.60 \\
18.90 \\
21.30 \\
23.90 \\
26.40 \\
29.10\end{array}$ & $\begin{array}{r}0.00 \\
1.85 \\
3.90 \\
5.95 \\
7.90 \\
9.95 \\
12.00 \\
14.80 \\
16.00 \\
18.85 \\
21.35 \\
23.85 \\
26.40 \\
29.05\end{array}$ \\
\hline
\end{tabular}


8

Table 3 (continued)

Data

Isxpension Inchos/1000

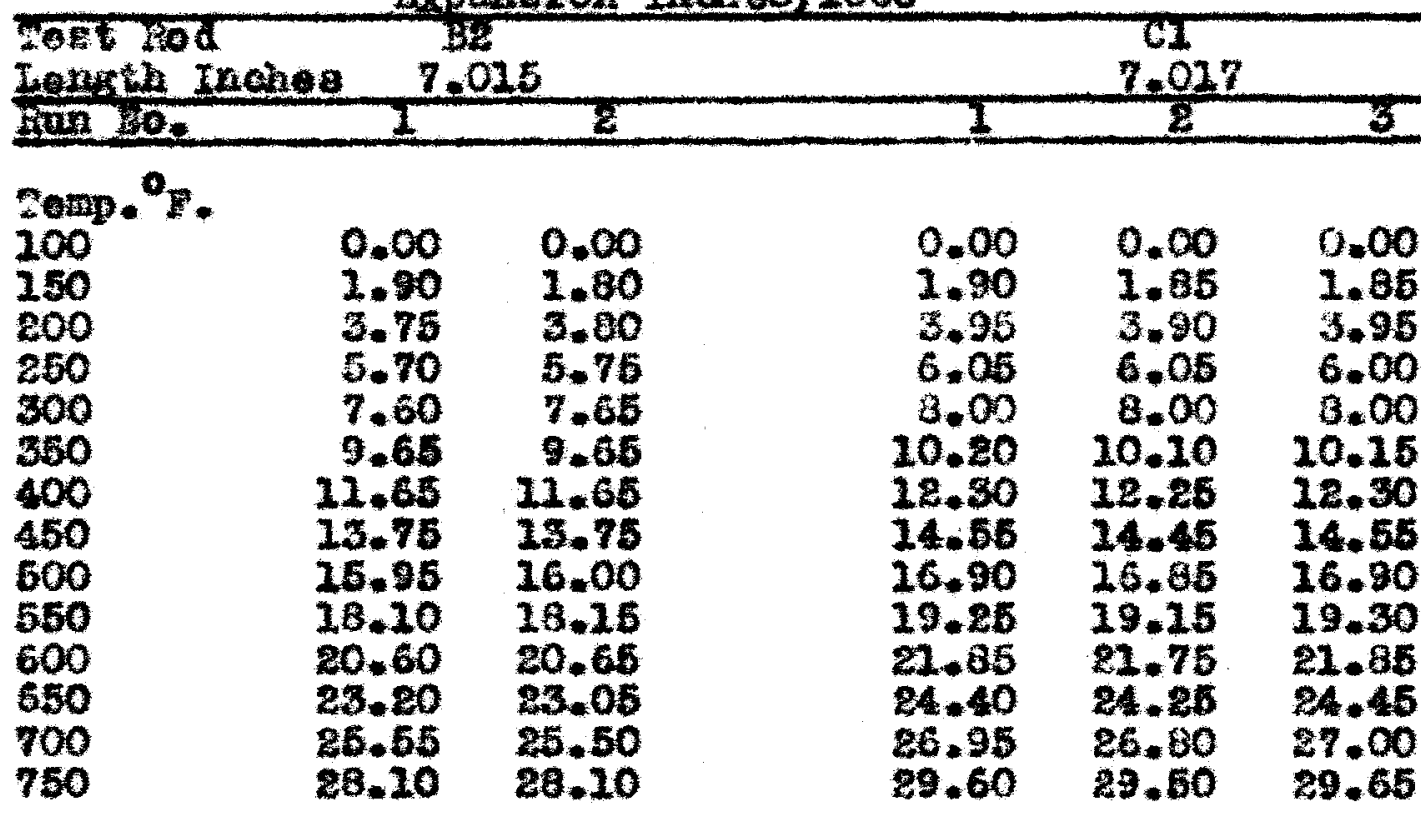

\begin{tabular}{|c|c|c|c|c|c|c|}
\hline $\begin{array}{l}\text { Tert kod } \\
\text { length I }\end{array}$ & & $\begin{array}{c}\mathrm{C} 2 \\
7.058\end{array}$ & & & $\begin{array}{c}D I \\
7.02\end{array}$ & \\
\hline $\operatorname{con} 10$. & -1 & 2 & 3 & $I$ & 2 & 3 \\
\hline $\begin{array}{l}50 \text {. } \\
200 \\
150 \\
200 \\
250 \\
700 \\
350 \\
100 \\
460 \\
500 \\
550 \\
600 \\
650 \\
700 \\
750\end{array}$ & $\begin{array}{r}0.00 \\
1.80 \\
3.70 \\
5.65 \\
7.60 \\
9.45 \\
11.40 \\
13.60 \\
15.70 \\
18.00 \\
20.45 \\
22.95 \\
25.70 \\
27.75\end{array}$ & $\begin{array}{r}0.00 \\
1.75 \\
3.75 \\
5.65 \\
7.50 \\
9.55 \\
11.55 \\
13.50 \\
13.60 \\
17.05 \\
20.95 \\
22.90 \\
25.70 \\
27.50\end{array}$ & $\begin{array}{r}0.00 \\
1.80 \\
3.75 \\
5.65 \\
7.56 \\
9.55 \\
11.56 \\
13.65 \\
15.90 \\
16.05 \\
20.60 \\
22.96 \\
25.25 \\
27.00\end{array}$ & $\begin{array}{r}0.00 \\
1.60 \\
3.55 \\
5.35 \\
7.75 \\
9.15 \\
11.10 \\
13.05 \\
15.00 \\
17.35 \\
19.50 \\
21.85 \\
24.15 \\
26.55\end{array}$ & $\begin{array}{r}0.00 \\
1.70 \\
3.60 \\
5.45 \\
7.25 \\
9.20 \\
11.20 \\
13.05 \\
15.25 \\
17.15 \\
19.50 \\
21.85 \\
24.10 \\
26.40\end{array}$ & $\begin{array}{r}0.00 \\
1.65 \\
3.55 \\
5.45 \\
7.25 \\
9.15 \\
11.05 \\
13.10 \\
15.20 \\
17.25 \\
19.55 \\
21.90 \\
24.15 \\
26.45\end{array}$ \\
\hline
\end{tabular}


rablo 3 (contineed)

Data

3ronansion Inches $/ 2000$

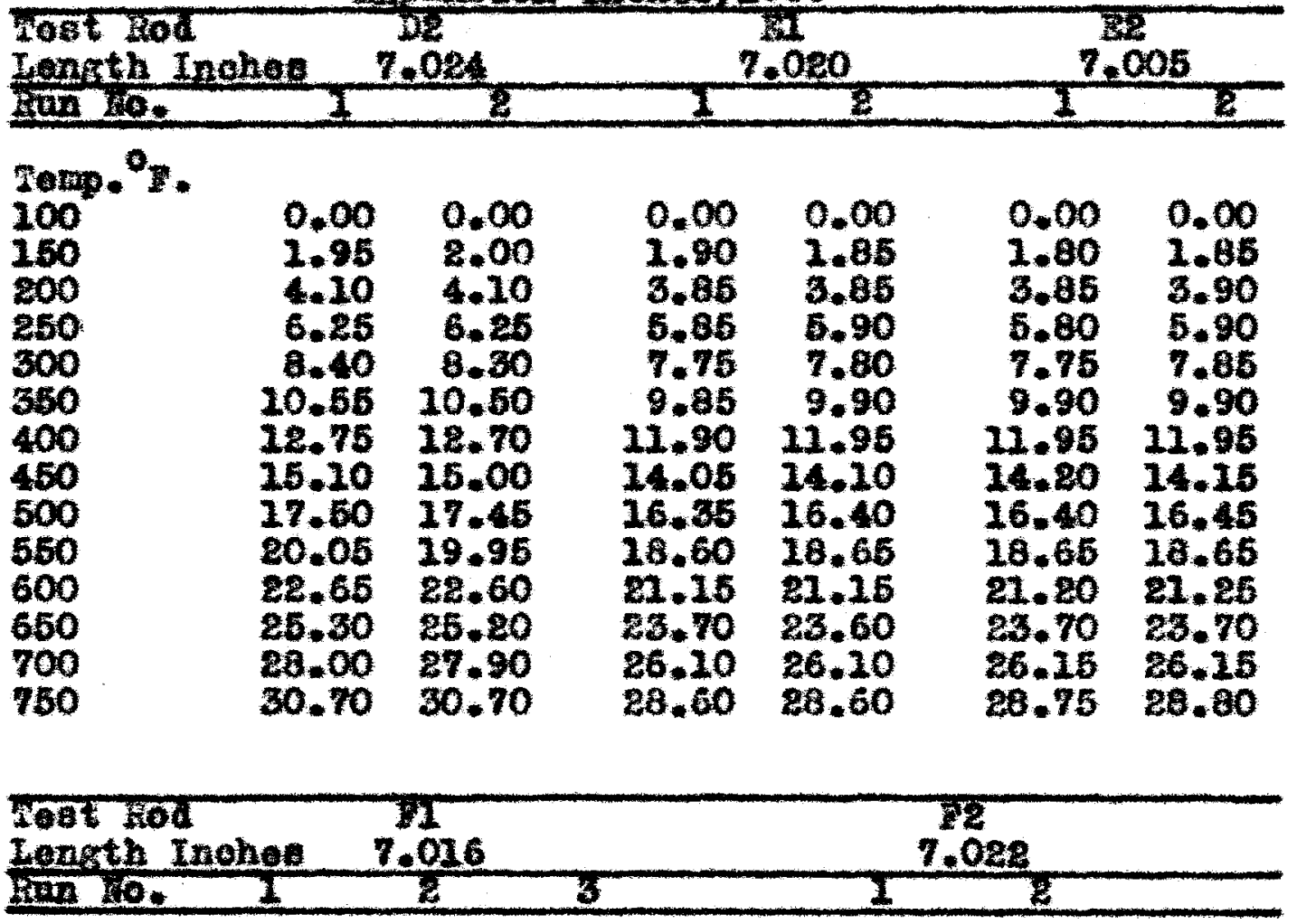

Temp. ${ }^{\circ} \mathrm{F}$.

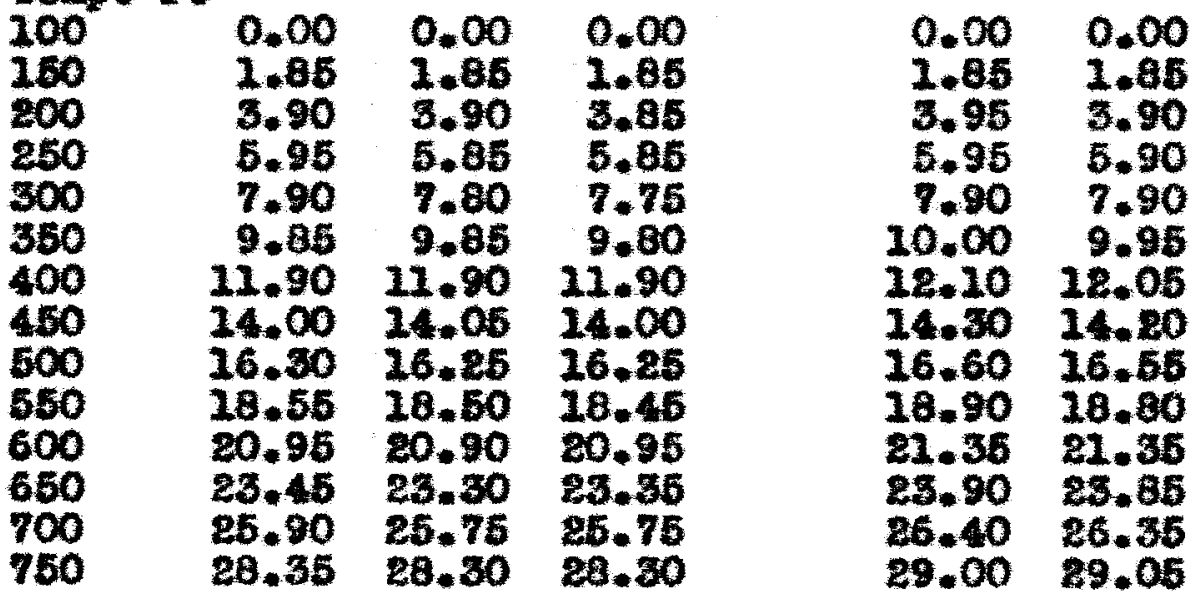


pable 3 (continued)

Data

Dxpansion Inahes 1000

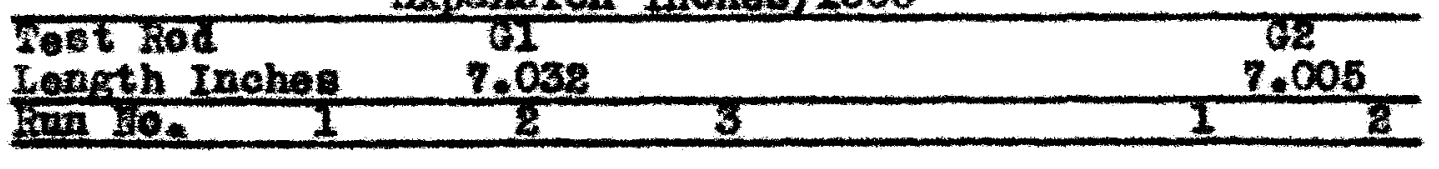

somp. 0.

100

150

200

250

300

350

400

460

500

550

600

660

700

750 $\begin{array}{lll}0.00 & 0.00 & 0.00\end{array}$

$1.65 \quad 2.75 \quad 1.75$

$3.65 \quad 3.70$

5.60

7.30

9.40

11.50

13.55

15.70

17.85

20.26

22.45

24.90

27.40
5.65

7.50

9.50

11.50

13.60

25.85

17.90

20.35

22.75

26.15

27.70
3.75

5.65

7.65

9.60

11.60

13.70

15.90

28.00

20.40

22.85

25.20

27.75
0.00

$1.25 \quad 1.90$

$4.05 \quad 4.06$

$6.25 \quad 6.15$

$8.15 \quad 0.25$

$20.30 \quad 10.35$

$12.45 \quad 12.45$

$14.70 \quad 14.65$

$17.15 \quad 17.06$

$19.50 \quad 19.45$

$22.05 \quad 21.95$

$24.55 \quad 24.45$

$27.00 \quad 27.05$

$29.65 \quad 29.65$

Teat Rod
Length Inohes 7.000
Fon 10.

Torp. ${ }^{\circ} \mathrm{z}$.

$\begin{array}{lrr}100 & & \\ 150 & 0.00 & 0.00 \\ 200 & 1.85 & 1.85 \\ 250 & 3.80 & 3.96 \\ 300 & 5.95 & 6.00 \\ 350 & 7.90 & 6.00 \\ 400 & 10.00 & 10.05 \\ 450 & 12.10 & 12.15 \\ 500 & 14.35 & 14.40 \\ 550 & 16.70 & 16.70 \\ 600 & 19.10 & 19.05 \\ 650 & 21.55 & 21.60 \\ 700 & 24.05 & 24.10 \\ 750 & 26.60 & 26.65 \\ & 29.20 & 29.25\end{array}$

0.00

1.75

3.75

5.70

7.60

9.60

11. 60

23.70

16.00

18.85

20.65

23.10

25.50

20.06
0.00

2.80

3.80

5.75

7.65

9.70

11.70

23.80

16.05

18.25

20.70

23.25

25.50

28.06 
1ี สนชอ 6

Graphieal Representation of Date

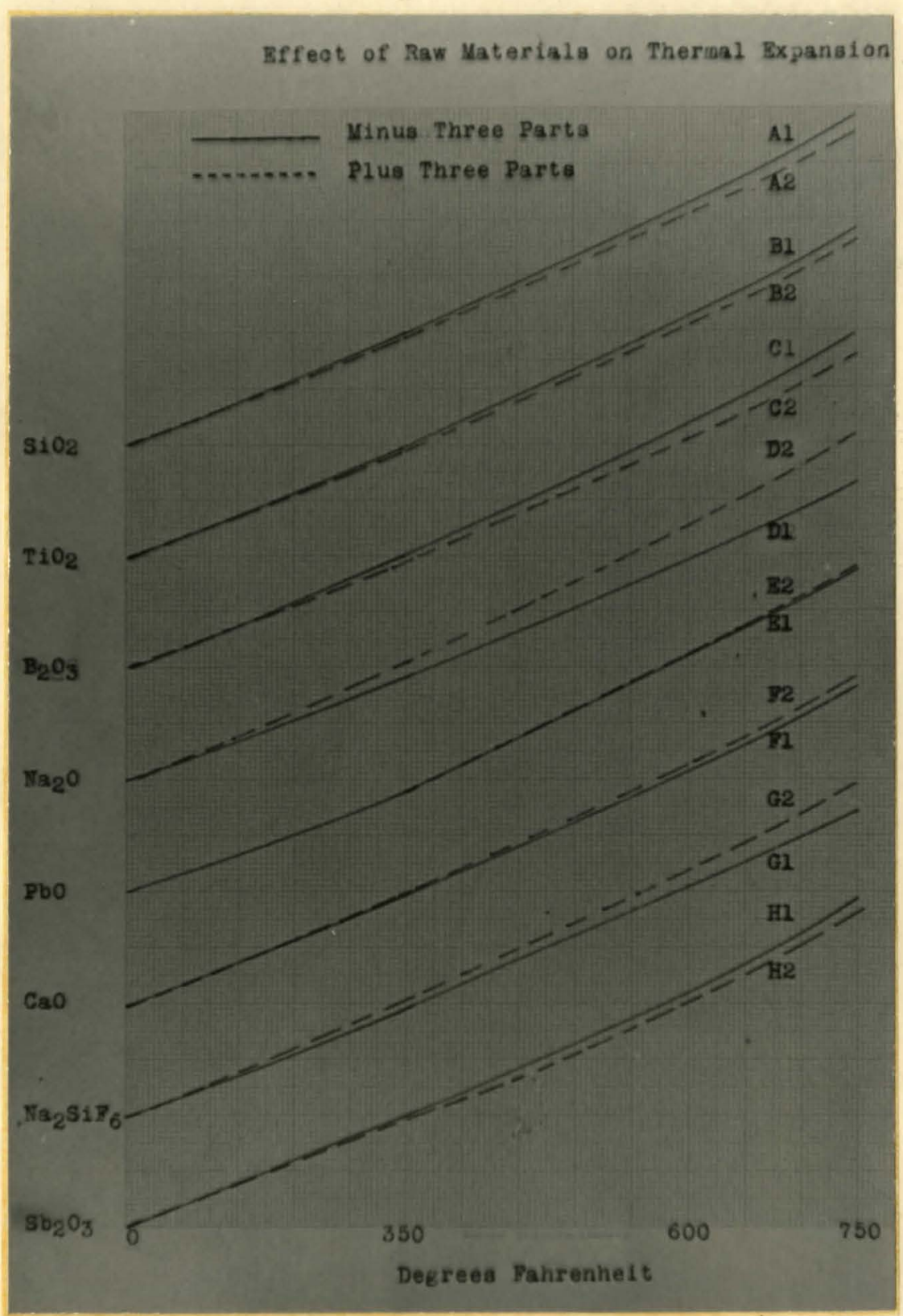


CALCU: Tons 
CALCTLATIOHS

Rosults of the on:ly investlgations of the therasi expenston of glasses wer exprossed as the

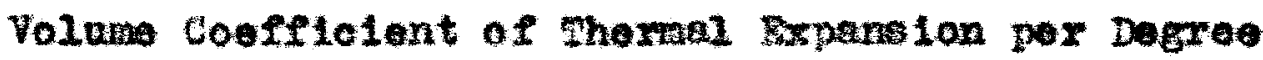
Contlgrede. Leter workers heve followed the same practice in ordar to direot comarisone. The volume coeffletent nay be obtalned with nepligtble error by matiplying the linent coefilelent by three. The volume voefficlent of therwal axpansion was obtuined for each onamel inoluded in this investlgation, the following forma beine need:-

$$
\cos =\frac{\Delta z}{\pi_{0} x \Delta x} \times \frac{9}{6} \times 3
$$

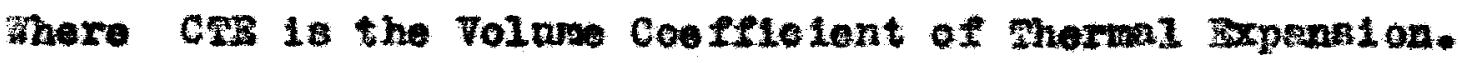
$I_{0}$ is the length of the feat rod at $70^{\circ} \mathrm{z}$. $\Delta I$ io the expannion between $100^{\circ} \geqslant$ and $750^{\circ}$. $\Delta$ Io the temexnture interval, $650^{\circ} \mathrm{z}$. $9 / 5$ is the converaion footor Pahrenhelt to centigrade.

3 is the conversion fector from inetr tante to volume nate. 
Oxide Feotors vere onlovisted frow the onamel ooefficients by wenne of the sorara show below, in which the addive chereter of the oxides is notamed:-

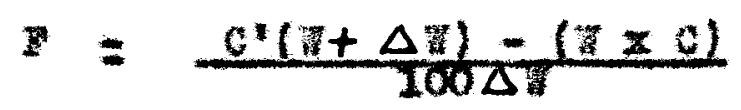

Where 1e the oxide Fector for the oxide wich has beon varled to change the thermel exponston.

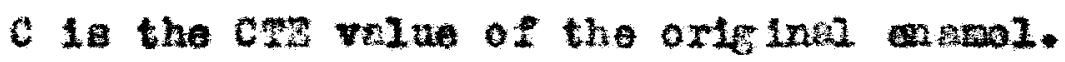
c'is the CFr value of the enasel whleh has boen alterad.

w If the number of parts by welght of the

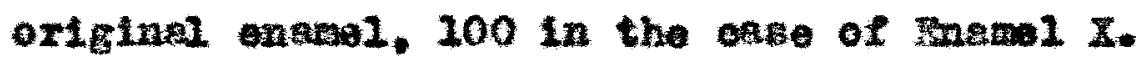
$\Delta$ 18 plae or alaus 3, representing the namber of perts by weight of the oxide which has been addod to or aubtracted from the orf ginal onamel. It 13 andtiplied by 100 in the denowinator ia order that the rosulting fector w11 reprebent the affect of one per cent of the oxide. 
The ealoniated volume coefflelents of the ran expansion for the ernuel compostions tented are shown in rable 4. together 1 th the comegyonalng cal calated oxide factors. The tro ranen obtelned for enoh oxide factor wero weragod and the averege vilues aro alao included in pable 4. In rable 5 the oxide psotors obtained in this investigetion ano shown in comparis on Wh oxide feotors, for the ane axides, which have been taken from the 11 terature. 
Fonde 4

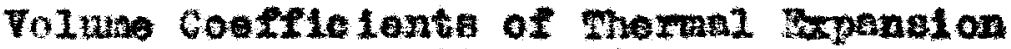
and Oxide Zastors

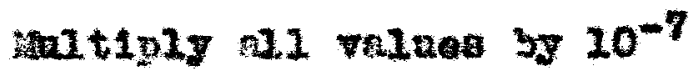

Mat 1

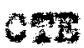

$$
\text { OxIde }
$$

$0 \times 100$

LVerage

Yeotor oxian pactor

$\mathbf{x}$

338.6

A1

8.0 .0

$\mathbf{A 2}$

328.7

$$
\begin{gathered}
\$ 10_{2} \\
710_{2}
\end{gathered}
$$

343.7

Be

01

ce

D2

D2

I.

ne

$n$

$p e$

01

62

I2

He

389.8

300.7

327.2

322.5

36.1

w

"

$\mathrm{ma}_{2} \mathrm{O}$

$n$

Pbo

342.3

335.1

343.4

coo

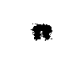

n

361.6

$\mathrm{sb}_{\mathrm{e}} \mathrm{O}_{\mathrm{g}}$

0.82

0.02

0.17

1. 70

1.45

1.57

$\mathrm{B}_{\mathrm{Z}} \mathrm{O}_{\mathrm{B}} \quad-0.56$

$-0.50$

$-0.53$

11. 79

11.98

11.82

3.39

4. 35

3.87

4.48

5.07

4.78

$\operatorname{ma}_{2} 817_{6} 6.94$

7.80

7.41

0.70

0.98

0.84 
Teb10 5

Comparison of oxtate petor:

Jultiply al ver nog by $10^{-7}$

\begin{tabular}{|c|c|c|c|c|c|}
\hline oxide & B & 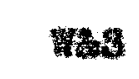 & MERI & 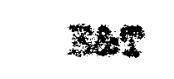 & 262 \\
\hline $3^{310_{2}}$ & 0.17 & 0.8 & 0.0 & 0.16 & 0.25 \\
\hline $10_{2}$ & 2.67 & $-\infty$ & 4.2 & $-\infty$ & - \\
\hline$e^{0} 3$ & -0.58 & 0.1 & 0.2 & -2.98 & $\cdots$ \\
\hline${ }^{2}{ }^{0}$ & 12.82 & 10.0 & 10.0 & 12.96 & 12.50 \\
\hline & 3.87 & 3.0 & 4.2 & 3.18 & $m$ \\
\hline & 4.78 & 5.0 & 6.0 & 4.89 & $\rightarrow-m$ \\
\hline $2^{817}$ & $6^{7.42^{8}}$ & $m$ & - & $m-$ & $-\cdots$ \\
\hline$b_{2} 0_{3}$ & 0.84 & $-\cdots$ & $4.0^{b}$ & $-\infty$ & $-\infty$ \\
\hline
\end{tabular}

c. 筹o correspondine val be hown in refarenees.

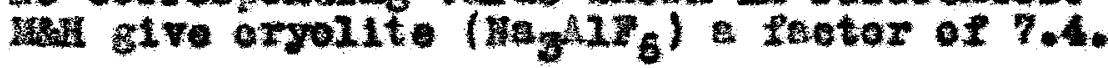

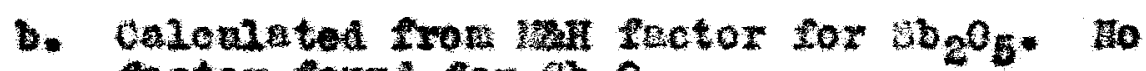

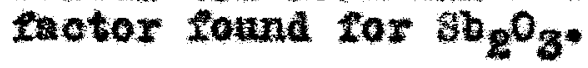

3 Fators derivod in thit investigation.

was Inkelman and Sohott.

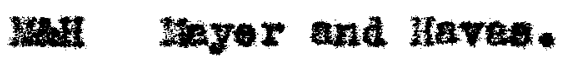

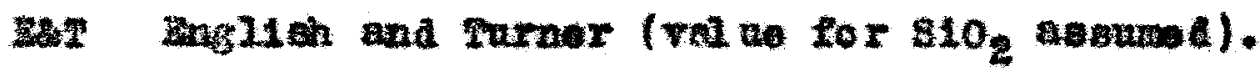

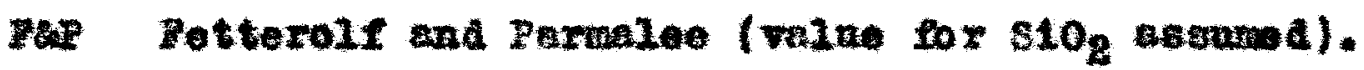

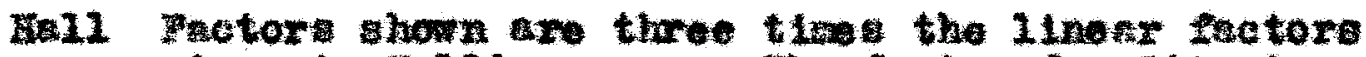
GTran in Hall's perper. The factor for $310_{2}$ is trien trow his curve in whieh it verles trot 1.6 for compost tion contrining 20 s alllea down to 0.25 ior 100, 61110a. 
DTECUSSTOR 


\section{Drscoss ron}

Coneldering the data in Fable 3 , it will be observed that correaponding values of oxpanston for the ane enamel newally oheok within 0.05 thousand th of an inoh for thoee runs in whioh the totel oxpansion differenee does not weed this figure. Onis raraly do the IIfferences exeed 0.10 thonsendth of Inoh. From thlo it wowld appoer that the regatrod ohoch to Fithin 0.05 thouenath of an inch wag reasonably well chosen. In the ase of masel $n$ the first two runs seomed to oheck but after the rendinge were correated to antial reading of zero at $100^{\circ} \mathrm{F}$. It we found that the two rendings just preoedding the final reading were more than 0.10 thousand th of an lnch afferent and it was bolleved adviable to anke third ran. Whoro such aifferences wore found woll romoved frow the senificant first and final rozdinge, with good cheohs on ef ther side, repest rans rore deenod unnoeeseary. Adntting a posalble exror of 0.05 thousand th of an Inch for the first and firal readinge of ench ron, It is obeerved that 1 these errore were in oppesite directione there wovld be plas or alnus arror of 0.10 thoneand th of an Inoh, or epproximately 0.35\%. In calowisting the wolno coefflelent of therral expension the sam maximerror 
of $0.35 \%$ may be obtainot. However the for mia for caleulating oxide faotors oaves the error to boode en aditive nuerical vaine mich mat be olthor positive of negatiro. It can be sown that this additive error has a taxim value of plas or minue $0.4 \times 10^{-7}$. It 10 ovident that a wah andior error then this would account for the difference in the two oxide frotore obteinod tor $\mathrm{SLO}_{2}$ * In general the reaconebly aloge acroesent of the peirs of oxlde frotore Indioste a wach mallor and largels compenbeting error in wont cabea.

The difference in the oxlde flotors derived for pbo is greater than would oock oven by the remote poobibllity of deriving the waxtane error for oach Inotor in opposite aireotions. A poneible explenntion 11 es in the fect that Pbo has relatively large influence on the coftenine point of entameI. It w111 bo obeerved that in general those neterials whioh tend to lower the eoftening polnt of the anared how higher factore in the anovelo which contaln the in erenter proportion. This effect may poselbly resch a max In the che of Pbo. In this connection it showld be pointed out thet winkelmann and gohott and Wayer and Heras, ustng of milar nethods and compost tions, obtained 
quite different faotore for Fbo although genorally in alose agreement.

The aerived oxide faetors are in botter general agreanent with thoee of inglieh and sumer than with the others shom in fable 5 . The val to of the fretor

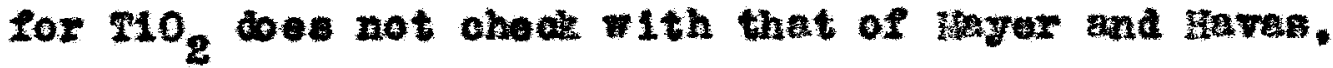
the only one found in the litereture, belng condiderably 10wer. The fnetor for $\mathrm{Sb}_{2} \mathrm{O}_{3}$ is also mah lowor than that on calated from the linyer and Hava factor for $\mathrm{Sb}_{2} \mathrm{O}_{5}$. Both of theae axldes are probnbly araphoter10 and it is calte conelvable that their effocte on expanaion wonld differ considerebly with the compestion of the glase or onawel in which they wero ueed. The derived fretor for $\mathrm{B}_{2} \mathrm{O}_{3}$ does not ohect with any of the othere. In this connection, Bngliah end ramer found the effect of $\mathrm{B}_{2} \mathrm{O}_{3}$ on expension ald not follow the genoral adaltive rale. Ae the proportion of $\mathrm{B}_{\mathrm{g}} \mathrm{O}_{\mathrm{g}}$ in Elass ma inoressed. Ite offoet on axpant lon decressed to miniman and then increased. The range of ractors ehom for this oxide Fould tend to confirm this finding. HaI1's result aro probebiy explat nabie in the 11ght of his heving worked with gase compeitione

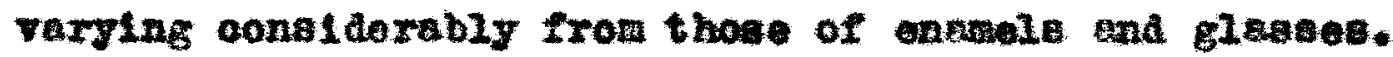
His assignment of a partable fnotor to sillen is 
interesting, al though not in egroement with the result seported here nor with those of other imveatiBators.

As a natter of interast, and to of how oxles fuotors aro usod, those derived in this investigntion are weed below to calculate the wiame coefficlent of tharwal expanelon of andel $x$.

\begin{tabular}{|c|c|c|c|c|c|c|c|c|}
\hline $510_{2}$ & $\$ 0$ & $\mathbf{x}$ & 0.17 & $x$ & $10^{-7}$ & 6.80 & $\mathbf{x}$ & $10^{-7}$ \\
\hline $\mathrm{NLO}_{2}$ & 6 & $x$ & 2.57 & $n$ & $n$ & 9.42 & " & $n$ \\
\hline $\mathrm{B}_{2}{ }^{0} 3$ & 6 & $x$ & -0.58 & $"$ & $"$ & -3.18 & $*$ & * \\
\hline${ }_{2} 0$ & 15 & $\mathbf{x}$ & 11.81 & " & $n$ & 177.15 & " & " \\
\hline pro & 15 & $x$ & 3.87 & $"$ & $"$ & 58.05 & 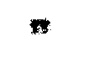 & " \\
\hline $\mathrm{caO}$ & 6 & $x$ & 4.78 & $n$ & " & 28.68 & $"$ & $"$ \\
\hline $\mathrm{ma}_{2} \mathrm{sin}_{6}$ & 6 & $\mathbf{x}$ & 7.41 & $n$ & " & 44.46 & $"$ & $n$ \\
\hline $\mathrm{sb}_{2} \mathrm{O}_{3}$ & 6 & $x$ & 0.84 & * & $"$ & 5.04 & 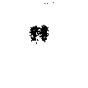 & $"$ \\
\hline & & & & $\mathrm{c}$ & & 326.42 & & \\
\hline
\end{tabular}

The roenlt of the enlonjated ralue difter from the weesured value by a 11thlo levs then four por cent. In considering this alference it net be reweenbered that the oxide factore were determined for comperatively 12 variations and there le resson to bellove that theg would not apply acourctely to tho whole amonte of each oxice. 
Andrew and How oaloulated expansion oostlelonte of difforent onkela by threa dfferent thoda. ilgniflantly. In ovory cate the reant wa lawor than the measured value, the rariation ranglng from two to tan por cont.

These rean2ts confira the opinton of provions inventigators that oxide factors aro aditive ond ovex narrov ranges of compos tione. Feverthelese they do ave dofintte value thlah it incrobed conalderably if they have been derived within the composi tion range In wioh they are to be ppolied. The factors obtaina in this investigation w1II poral the changlne and

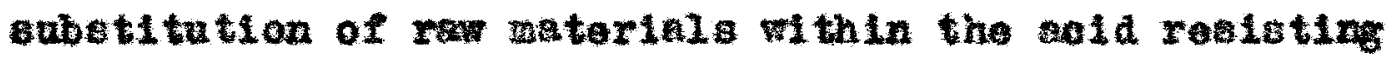
anawel renge thithout exceeding the permanable variation

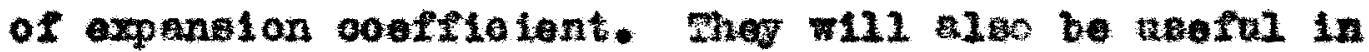
formula the enmal of other types with ane regard being given to the sprexisation of the reanlte. The oxide fector for $\mathrm{M1O}_{2}, \mathrm{~B}_{2} \mathrm{O}_{3}$, and $\mathrm{Sb}_{2} \mathrm{O}_{3}$ are of partloular Intereat aines it is erident that eren spoxinate taotors for these oxides, In the range covered, have hitherto been laoking. Aa far as on be determined a factor for $\mathrm{He}_{\mathrm{2}} \mathrm{B19}_{6}$ has not been avallable prevtonaly.

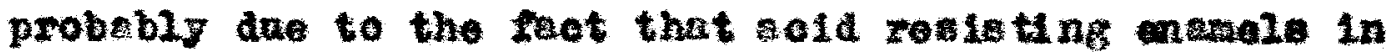
whioh 1 to we is nenrly aniverabl, have been developed largely in recent years. 
sunnater 
The Volume coefflolents of Therael sxpension

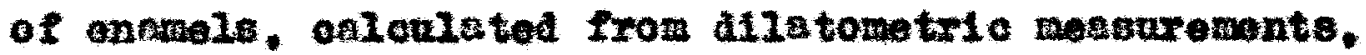
were obtaled with aximu exror of lode than one half of ons per cent.

It was found hat orror of etpaneton wescure-

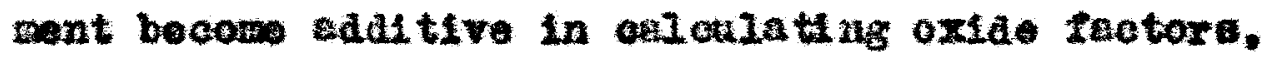
incresolng the degree of approxingtion in respet to theos.

Oxide pactors for $\mathrm{s}_{2} \mathrm{O}_{2} \cdot \mathrm{se}_{2} \mathrm{O}$, po, and cao, derived in this investigstion, were forna to be in resconably alose agreennt with factors derived prevlonely by Bnglish and purner. Oxide potorb for $\mathrm{S1O}_{2} \cdot \mathrm{B}_{2} \mathrm{O}_{3}$, and $\mathrm{Sb}_{2} \mathrm{O}_{3}$ alffered considerably Iron those of provious investigators, and are belleved to be nore acourate for wee in connection with seld reste ting enamela.

The opini on of othe $F$ investlgator that cxide Factora enn be considered additivo only through the

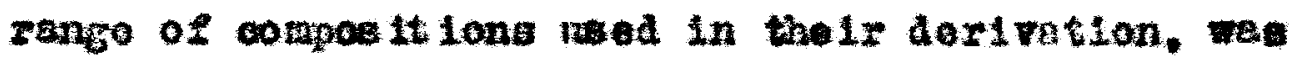
oonfizrod. 
Evidenee wag to und that a set of oxide factore whioh are oultable for calowating the effoot of amil change in compostion upon the expansian of a cortain type of enarial. nog not give accurate reaute If reed to onlonlate the oceffletent of expans ion of the complote onamel. 
BIBLIOORAPEX 


\section{BrBLroGaptra}

(1) Eoore, H., "Gleases, Organtc and Inorgante." J. of Glase Tech. 느 (100), 347 (1939).

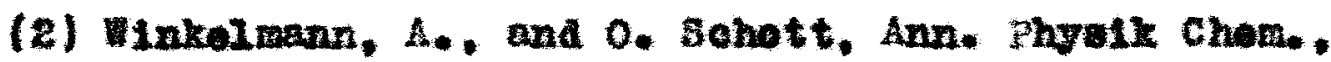
52. 735 (1894). Fovertadt, H., "Jene Glas", tranklation by Brerett, J. D. and A., Shoml12an, Hew York. 1902.

(3) Wayer and Havee, "Coeffleient of Buars lon of Mnamele and Their Chosion compos tion." Sprechser, 노, 497 (1909): 소, 188, 207. $220(1911)$.

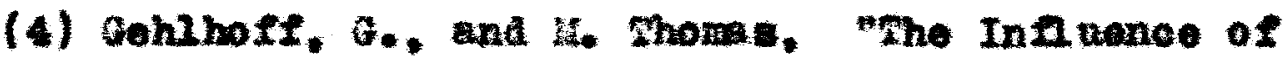
the corposition on the phyeloel properties of Glasea," z. tooh. Bhraik. I (3), 208 (1926).

(5) Eglish, s., and 7. I. 8. Turnor, "ReLati onahip botween Chomleal coppost tion and the Thermal Axpanst on of G2aeses," J. Am. Ceram. 300., $20(8), 561$ (1927): 12 (18), 760 (1929). 


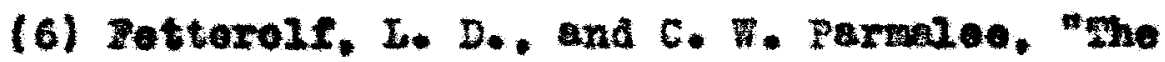
21teote of Sodv. Bariun, and zino on the Suatiolty and Thorant Sxpansion coefelolents of blase," J. Am. Coram. 300. $12(3) .198(1989)$.

(7) He11. H. "The Inhuence of choralas Cormoal tion on the phyeleal properties

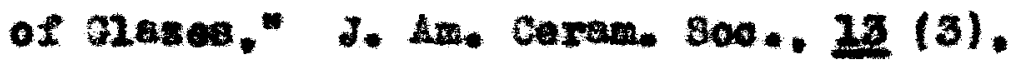
$102(2950)$.

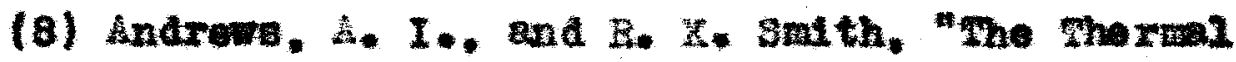
manaton of sheet Iron Ground coat Bnano2s," J. Sn. Coxam. soc. $16(7)$. $328(1938)$.

(9) Andrewn, A. 1., and R. 3. Howe, whe Befeet of

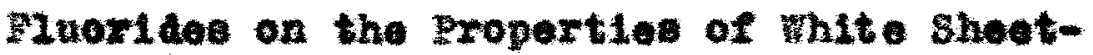

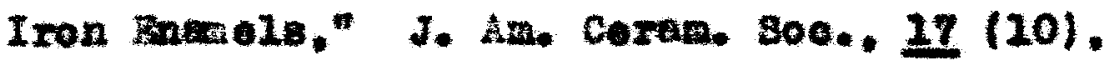
$298(1934)$.

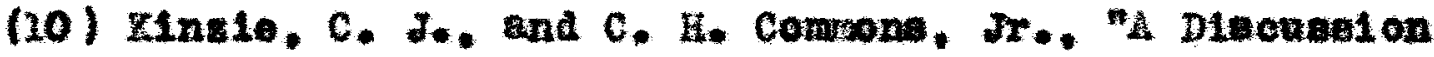

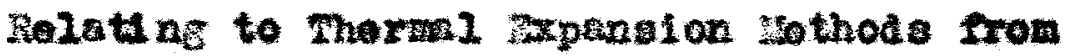
Theoretion and Praotionl gtanapolnts." J. An. Ceran. Soc. $18(10), 206(1935)$. 
(11) Dahl, A. I., Bur, of stand, Jonm, of Roacaroh, 24 (2), $205(1940)$. 